\title{
Thermal-Hydraulic Assessment of Concrete Storage Cubicle with Horizontal 3013 Canisters
}

\author{
F. J. Heard
}

Numatec Hanford Corporation

Richland, WA 99352

U.S. Department of Energy Contract DE-AC06-96RL13200

EDT/ECN: 626231

Org Code: 82600

B\&R Code: EW7040000
UC: 721

Charge Code: 100790/ BA30

Total Pages: 7580

Key Words: plutonium, storage, thermal, temperature, 3013 canister, concrete cubicle, 3013

\section{Abstract:}

The EIDAP computer code was used to perform a series of analyses to assess the thermal-hydraulic performance characteristics of the concrete plutoium storage cubicles, as modified for the horizontal placement of 3013 canisters. Four seperate models were developed ranging from a full height model of the storage cubicle to a very detailed standalone model of a horizontal 3013 canister.

TRADEMARKDISCLAIMER. Reference herein to any specific commercial product, process, or service by trade name, trademark, manufacturer, or otherwise, does not necessarlly constitute or imply its endorsement, recommendation, or favoring by the United States Government or any agency thereof or its contractors or subcontractors.

Printed in the United States of America. To obtain copies of this document, contact: Document Control Services, P.O. Box 950, Mailstop H6-08, Richland WA 99352, Phone (509) 372-2420; Fax (509) 376-4989.

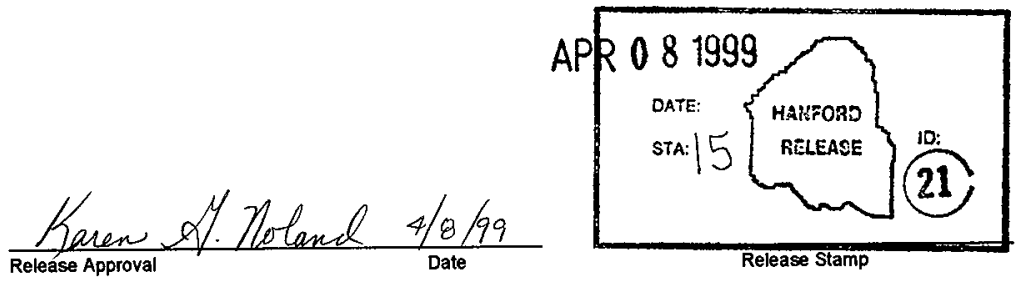

\section{Approved For Public Release}


HNF-3830, Rev. 0

\section{LIST OF FIGURES}

Figure 1A. Representative View of a Storage Vault................................... 10

Figure 1B. Floor Plan View of a Storage Vault.........................................11

Figure 2. Isometric View of Storage Cubicle, 3013 Canister, and Ventilation Cross Duct......12

Figure 3. Elevation View of 3013 Canister Support Rack...............................13

Figure 4. Section View of 3013 Canister Support Rack...............................14

Figure 5. Plan View of 3013 Canister Support Rack.................................. 15

Figure 6. Final Assembly Sequence of 3013 Canister...............................16

Figure 7. Section View of a Vertical 3013 Canister......................................17

Figure 8. $\mathrm{PuO}_{2}$ Powder Level Within a Vertical 3013 Canister.............................18

Figure 9. Possible $\mathrm{PuO}_{2}$ Powder Configurations Within a Horizontal 3013 Canister...........19

Figure 10. Thermal Model of a Full Height Storage Cubicle ...............................20

Figure 11. Thermal Model of a Single 3013 Canister Within a Storage Cubicle at a Given

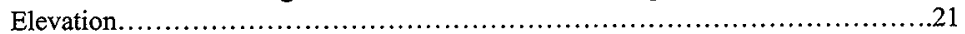

Figure 12. Thermal Model of a Standalone 3013 Canister.................................22

Figure 13. Axi-symmetric Thermal Model of a Single Horizontal 3013 Canister Within a

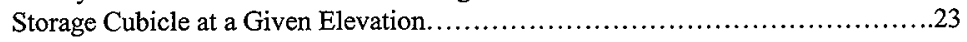

Figure 14. Ambient Air Temperatures Within Vault Versus Time During a Simulated Loss-Of-

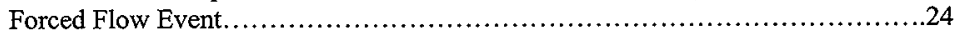

Figure 15. Thermal Conductivity of Plutonium Oxide in Dry Air Versus Density...............33

Figure 16. Steady-State Temperature Contours for a Full Height Storage Cubicle at Case 3A Conditions...................................................................... 41

Figure 17. Steady-State Temperature Contours for Upper Third of Storage Cubicle at Case 3A

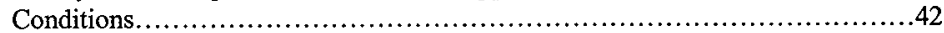


HNF-3830, Rev. 0

\subsection{EXECUTNE SUMMARY}

Given horizontal 3013 canister storage, four separate models were developed for the thermal assessment of the modified concrete plutonium storage cubicles. This was necessary to handle the change in dimensional scales ranging from the full height concrete storage cubicles to the relatively thin walls and small separation distances among the three containers that comprise a 3013 canister. The thermal-hydraulic models increase in detail and complexity as the dimensional scale decreases.

The goal of these analyses was to determine the peak concrete and component temperatures during nominal steady-state operations for various ventilation flow rates and inlet temperatures, as well as the peak transient temperatures associated with a postulated loss-of-forced ventilation flow (LOFF) event. The analyses focused on a single concrete storage cubicle with maximum decay heat. These analyses are expected to provide general guidance on the feasibility of using the existing, but modified concrete storage cubicles with horizontal placement of 3013 canisters.

NOTE:The subject thermal analyses are considered conceptual and must be reviewed for applicability prior to implementing horizontal storage of 3013 canisters. Any revisions to the current design concept, technical bases, and assumptions, as documented within this report, may require additional thermal analyses to demonstrate compliance with peak concrete temperatures.

The following conclusions are made:

1. The nominal peak concrete temperatures are expected to be less than $150^{\circ} \mathrm{F}$ during steadystate operations. Peak concrete temperatures range between $144^{\circ} \mathrm{F}$ and $148^{\circ} \mathrm{F}$ for the range of Case 3 conditions shown in Table 3. This is very close to maximum value of $150^{\circ} \mathrm{F}$, as recommended by the American Concrete Institute (ACI) for normal operations or any other long term period. However, the results are based on a series of conservative assumptions that are not expected to simultaneously occur within any one cubicle.

2. The peak concrete temperatures during a Loss-Of-Forced Flow (LOFF) event will exceed 200 ${ }^{\circ} \mathrm{F}$ within approximately 8 hours.

3. Uncertainties in the cubicle flow rate, inlet temperature, and canister heat loads could result in nominal steady-state peak concrete temperatures greater than $150^{\circ} \mathrm{F}$. These uncertainties can result from the following;

- Bypass or leakage flow through the various edge, lap, and upper gaps surrounding the front concret doors

- Inlet temperature variations due to seasonal or building heat loads

- Canister heat loads greater than 15 watts due to the buildup of Americium-241 and other high order decay isotopes. 


\subsection{CODE DESCRIPTION}

The Fluid Dynamic Analysis Package (FIDAP' computer program was used to develop the thermal-hydraulic models of the 3013 canisters and concrete storage cubicles and to perform the analyses. FIDAP has been validated and verified for use at Hanford (Heard 1994) for the performance of quality affecting analyses.

FIDAP is a commercially available general purpose computer package that uses finite element methods (FEM) to simulate many classes of single or multi-phase compressible or incompressible flows, including heat transfer, and mass transport of chemical species $(<15)$ in both nonreacting and reacting flows. The simulation can be either steady-state or transient and can model flows in complex arbitrary geometries that are 2-D, axi-symmetric, or 3-D. Mixed coordinate or moving/rotating systems are supported.

FIDAP can be thought of as a single environment for the simulation of thermal-hydraulic problems and can be viewed as an integrated set of components and program modules designed to perform all aspects of model generation, automatic meshing, or paving, problem setup including view factor calculations, solving the resulting matrix of simultaneous finite element forms of the equations for the conservation of momentum, mass, and energy, and post-processing (i.e., visualizing) the results. The post processing capabilities of FWAP are considered one of the industries best.

FDAP is currently active on a Silicon Graphics Power Indigo-2, with an R-10000 CPU, $256 \mathrm{Mb}$ of main system memory, running under the IRIX 6.2 operating system with FORTRAN 77 Version 7.0. The IRIX 6.2 operating system uses a 64 -bit real and integer single precision wordlength (128-bit double precision).

FIDAP is a registered trademark of Fluid Dynamics, Inc., Evanston, I11inois. 


\section{To: (Receiving Organization)}

EV Weiss, PFP Transition Engrg

5. Proj./Prog./Dept./Div.:

PFP

\section{Originator Remarks:}

Transmittal of HNF-3830, Rev. 0, "Thermal-Hydraulic Assessment of Concrete Storage Cubicle with Horizontal 3013 Canister

11. Receiver Remarks:

11A. Design Baseline Document? $O$ Yes

3. From: (Originating Organization)

NHC Engrg Analysis \& Modeling

6. Design Authority/Design Agent/Cog. Engr.:

F. J. Heard

\begin{tabular}{|c|c|c|c|}
\hline \multicolumn{4}{|c|}{ 4. Related EDT No.: } \\
\hline \multicolumn{4}{|c|}{$\begin{array}{l}\text { 7. Purchase Order No.: } \\
\text { N/A }\end{array}$} \\
\hline \multicolumn{4}{|c|}{$\begin{array}{l}\text { 9. Equip./Component No.: } \\
\text { N/A }\end{array}$} \\
\hline \multicolumn{4}{|c|}{$\begin{array}{l}\text { 10. System/Bldg./Facility: } \\
\text { N/A }\end{array}$} \\
\hline \multicolumn{4}{|c|}{$\begin{array}{l}\text { 12. Major Assm. Dwg. No.: } \\
\text { N/A }\end{array}$} \\
\hline \multicolumn{4}{|c|}{$\begin{array}{l}\text { 13. Permit/Permit Application No.: } \\
\text { N/A }\end{array}$} \\
\hline \multicolumn{4}{|c|}{$\begin{array}{l}\text { 14. Required Response Date: } \\
\mathrm{N} / \mathrm{A}\end{array}$} \\
\hline (F) & (G) & $(\mathrm{H})$ & (1) \\
\hline $\begin{array}{l}\text { Approval } \\
\text { Desig- } \\
\text { nator }\end{array}$ & $\begin{array}{l}\text { Reason } \\
\text { for Trans- } \\
\text { mittal }\end{array}$ & $\begin{array}{l}\text { Origi- } \\
\text { nator } \\
\text { Dispo- } \\
\text { stion }\end{array}$ & $\begin{array}{l}\text { Receiv- } \\
\text { er } \\
\text { Dispo- } \\
\text { sition }\end{array}$ \\
\hline $\mathrm{N} / \mathrm{A}$ & 1 & & \\
\hline & & & \\
\hline & & & \\
\hline & & & \\
\hline & & & \\
\hline & & & \\
\hline & & & \\
\hline
\end{tabular}

KEY
16.

\begin{tabular}{|c|l|}
\hline Approval Designator (F) & \\
\hline $\begin{array}{c}\text { E, S, Q, D OR N/A } \\
\text { (See WHC-CM-3-5, } \\
\text { Sec. 12.7) }\end{array}$ & $\begin{array}{l}\text { 1. Approval } \\
\text { 2. Release } \\
\text { 3. Information }\end{array}$ \\
\hline
\end{tabular}

17.

\begin{tabular}{|c|c|c|c|c|c|c|}
\hline $\begin{array}{l}\text { (G) } \\
\text { Rea- } \\
\text { son }\end{array}$ & $\begin{array}{l}(\mathrm{H}) \\
\text { Disp. }\end{array}$ & (J) Name & $\begin{array}{lll}\text { (K) Signature } & \text { (L) Date } & \text { (M) MSIN }\end{array}$ & $\begin{array}{l}\text { (G) } \\
\text { Rea- } \\
\text { son }\end{array}$ & $\begin{array}{l}\text { (H) } \\
\text { Disp. }\end{array}$ & (J) Name \\
\hline & & \multicolumn{2}{|l|}{ Design Authority } & & & \\
\hline & & \multicolumn{2}{|l|}{ Design Agent } & & & \\
\hline 1 & 1 & \multicolumn{2}{|c|}{ 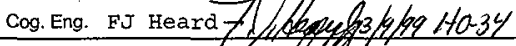 } & & & \\
\hline 1 & 1 & \multicolumn{2}{|c|}{ Cog. Mgr. Jo sloughter //f/ $3-16-99$} & $40-3$ & 1 & \\
\hline & & \multicolumn{2}{|l|}{ QA } & & & \\
\hline & & \multicolumn{2}{|l|}{ Safety } & & & \\
\hline & & \multicolumn{2}{|l|}{ Env. } & & & \\
\hline F. & I. $\mathrm{He}$ & ard $3 / 9 / 99$ & E. V. Weiss & & . & $y)$ kghter 3-16-85 \\
\hline $\begin{array}{l}\text { Sign } \\
\text { Orig }\end{array}$ & $\begin{array}{l}\text { fure of } \\
\text { lator }\end{array}$ & DDT Date & $\begin{array}{ll}\text { Authorized Representative } & \text { Date } \\
\text { for Receiving Organization }\end{array}$ & Dési & in Auth & nager \\
\hline
\end{tabular}

5. Post-Review
-Disposition (H) \& (1)
4. Review

6. Dist. (Receipt Acknow. Required)
1. Approved

2. Approved w/comment
3. Disapproved w/comment
4. Reviewed no/comment

5. Reviewed w/comment

\section{SIGNATURE/DISTRIBUTION}

(See Approval Designator for required signatures)

(See Approva Dest (G) (J)

$\begin{array}{ll}\text { (K) Signature } & \text { (L) Date }\end{array}$

(M) MSIN
21. DOE APPROVAL (if required)

Ctrl No.

Approved

Approved w/comments

Disapproved wicomments 


\title{
Thermal-Hydraulic Assessment of Concrete Storage Cubicle with Horizontal 3013 Canisters
}

\author{
F. J. Heard \\ Numatec Hanford Corporation \\ Richland, WA 99352 \\ U.S. Department of Energy Contract DE-AC06-96RL13200
}

EDT/ECN: 626231

Org Code: 82600

B\&R Code: EW7040000
UC: 721

Charge Code: 100790/ BA30

Total Pages: 7580

Key Wonds: plutonium, storage, thermal, temperature, 3013 canister, concrete cubicle, 3013

Abstract:

The FIDAP computer code was used to perform a series of analyses to assess the thermal-hydraulic performance characteristics of the concrete plutoium storage cubicles, as modified for the horizontal placement of 3013 canisters. Four seperate models were developed ranging from a full height model of the storage cubicle to a very detailed standalone model of a horizontal 3013 canister.

TRADEMARK DISCLAIMER. Reference herein to any specific commercial product, process, or service by trade name, trademark, manufacturer, or otherwise, does not necessanly constitute or imply its endorsement, recommendation, or favoring by the United States Government or any agency thereof or its contractors or subcontractors.

Printed in the United States of America. To obtain copies of this document, contact: Document Control Services, P.O. Box 950, Mailstop H6-08, Richland WA 99352, Phone (509) 372-2420; Fax (509) 376-4989.
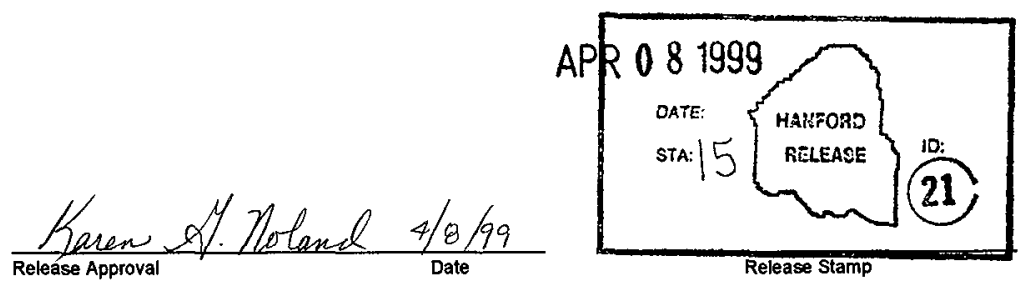
HNF-3830, Rev. 0

\title{
THERMAL-HYDRAULIC ASSESSMENT OF CONCRETE STORAGE CUBICLES WITH HORIZONTAL 3013 CANISTERS
}

Prepared by:

\author{
F. J. Heard
}

Numatec Hanford Corporation

March 1999 
HNF-3830, Rev. 0

\section{ABSTRACT}

The FIDAP computer code was used to perform a series of analyses to assess the thermalhydraulic performance characteristics of the concrete plutonium storage cubicles, as modified for the horizontal placement of 3013 canisters. Four separate models were developed ranging from a full height model of the storage cubicle to a very detailed standalone model of a horizontal 3013 canister. The goal of these analyses was to determine the peak concrete and component temperatures during nominal steady-state operations for various ventilation flow rates and inlet temperatures, as well as the peak transient temperatures associated with a postulated loss-of-forced ventilation flow (LOFF) event. The analysis methods and modeling assumptions are described. The results of the analyses are presented. The subject thermal analyses must be reviewed for applicability prior to implementing horizontal storage. Any revisions to the current design concept may require additional thermal analyses to demonstrate compliance with peak concrete temperatures. 


\section{TABLE OF CONTENTS}

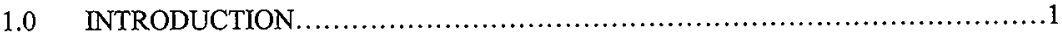

1.1 Purpose and Objective....................................................

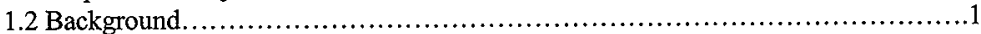

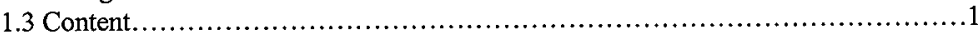

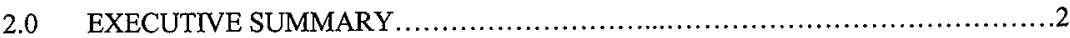

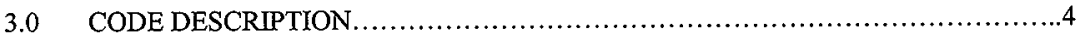

4.0 MODEL DEVELOPMENT, ANALYSIS METHODOLOGY, AND ASSUMPTIONS.5

4.1 Description of 3013 Canisters, Storage Cubicles, and Vault...................5

4.2 Steady-State Model Development.........................................6

4.2.1 Full Height Storage Cubicle Model..................................6

4.2.2 Unit Cell Models......................................................

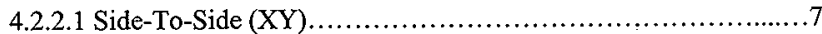

4.2.2.2 Detailed Standalone 3013 Canister Model.........................8

4.2.2.3 Front-To-Rear (RZ) ........................................ 8

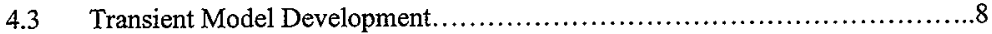

5.0 TECHNICAL BASES, ASSUMPTIONS, AND LIMITATIONS ...................25

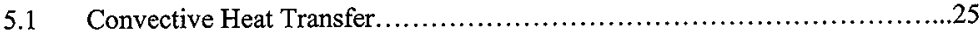

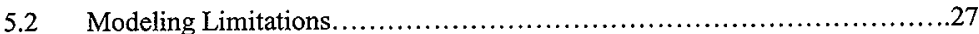

5.3 Miscellaneous Assumptions..............................................28

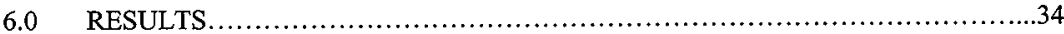

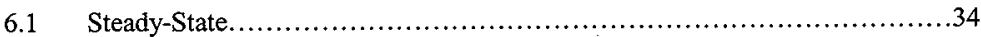

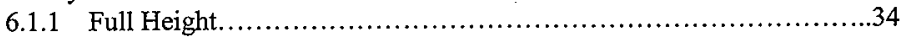

6.1.2 Axi-Symmetric....................................................

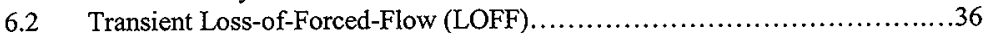

7.0 CONCLUSIONS AND RECOMMENDATIONS...............................56

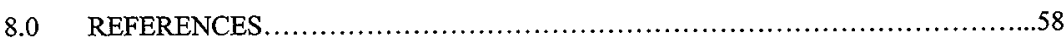

APPENDIX A User Subroutines for Evaluating Transient Convective Heat Transfer Coefficients APPENDIX B Material Properties 
HNF-3830, Rev. 0

\section{LIST OF TABLES}

Table 1. Convective Heat Transfer Correlations and Constants..........................31

Table 2. Thermal Conductivity of Plutonium Oxide Versus Density.....................32

Table 3. Comparison of Reference Conditions for Analysis..............................38

Table 4. Comparison of Steady-State Results From the Full Height Storage Cubicle Thermal Model at Reference Conditions..............................................39

Table 5. Comparison of Steady-State Results Versus Axial Position Within a Storage Cubicle at Reference Conditions....................................................40 
HNF-3830, Rev. 0

\section{LIST OF FIGURES}

Figure 1A. Representative View of a Storage Vault.......................................10

Figure 1B. Floor Plan View of a Storage Vault..........................................11

Figure 2. Isometric View of Storage Cubicle, 3013 Canister, and Ventilation Cross Duct......12

Figure 3. Elevation View of 3013 Canister Support Rack.................................13

Figure 4. Section View of 3013 Canister Support Rack................................14

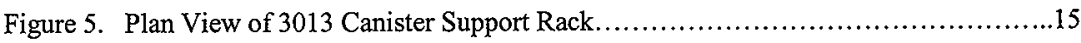

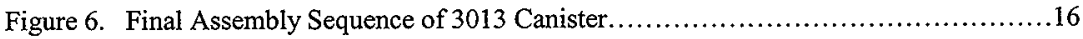

Figure 7. Section View of a Vertical 3013 Canister.......................................17

Figure 8. $\mathrm{PuO}_{2}$ Powder Level Within a Vertical 3013 Canister............................18

Figure 9. Possible $\mathrm{PuO}_{2}$ Powder Configurations Within a Horizontal 3013 Canister...........19

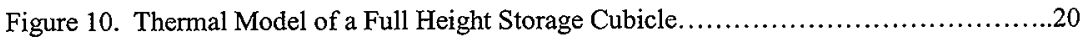

Figure 11. Thermal Model of a Single 3013 Canister Within a Storage Cubicle at a Given

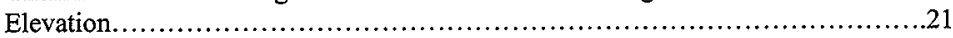

Figure 12. Thermal Model of a Standalone 3013 Canister..................................22

Figure 13. Axi-symmetric Thermal Model of a Single Horizontal 3013 Canister Within a Storage Cubicle at a Given Elevation.........................................23

Figure 14. Ambient Air Temperatures Within Vault Versus Time During a Simulated Loss-OfForced Flow Event.

Figure 15. Thermal Conductivity of Plutonium Oxide in Dry Air Versus Density 33

Figure 16. Steady-State Temperature Contours for a Full Height Storage Cubicle at Case 3A Conditions.

Figure 17. Steady-State Temperature Contours for Upper Third of Storage Cubicle at Case 3A Conditions. 
HNF-3830, Rev. 0

Figure 18. Steady-State Outlet Temperature Distribution Across the Top of the Canister Columns at Case $3 \mathrm{~A}$ Conditions.

Figure 19. Steady-State Temperature Contours for Left and Right Hand Side Concrete Walls at Case 3 A Conditions.

Figure 20. Steady-State Right-hand Side Concrete Temperature Versus Height Above Basepad at Case $3 \mathrm{~A}$ Conditions.

Figure 21. Steady-State Right-hand Side Concrete Temperature Versus Height Above Basepad at Case $3 \mathrm{~B}$ Conditions. .46

Figure 22. Representative Steady-State Temperature Contours for 3013 Outer Canister Showing Asymmetric Distribution at Case $3 \mathrm{~A}$ Conditions.

Figure 23. Velocity Vectors for Storage Cubicle at Case $3 \mathrm{~A}$ Conditions .48

Figure 24. Steady-State Temperature Contours for Axi-Symmetric Thermal Model At Case 3A Conditions.

Figure 25. Steady-State Temperature Contours for Front Third of Axi-Symmetric Thermal Model at Case 3A Conditions. .50

Figure 26. Front Concrete Temperature Versus Distance From Centerline for Minimum Front Gap .51

Figure 27. Peak Concrete Temperature Versus Time During LOFF for Full Height Storage Cubicle Model for Case $3 \mathrm{~A}(1 \mathrm{X})$ Initial Conditions .52

Figure 28. Peak Concrete Temperature Versus Time During LOFF for Axisymmetric Front-ToRear 3013 Canister and Storage Cubicle Model .53

Figure 29. Temperature Contours for Axisymmetric Thermal Model During LOFF at 11.08 Hours.

Figure 30. Temperature Contours for Axisymmetric Thermal Model During LOFF At 360 Hours. 
HNF-3830, Rev. 0

Nomenclature (SI and English Units)

\begin{tabular}{|c|c|c|}
\hline Quantity & SI & English \\
\hline Length $(\mathrm{L})$ & meter $(\mathrm{m})$ & Inches (in.) or feet (ft) \\
\hline Time $(t)$ & second (s) & Second (s) or hour (hr) \\
\hline Mass (m) & Kilogram $(\mathrm{Kg})$ & Pound (lbm) \\
\hline Temperature (T) & Kelvin $\left({ }^{\circ} \mathrm{K}\right)$ & Fahrenheit $\left({ }^{\circ} \mathrm{F}\right)$ or Rankin $\left({ }^{\circ} \mathrm{R}\right)$ \\
\hline Force (F) & Newton $(\mathrm{N})$ & Pound (lbf) \\
\hline Energy & Joule $(\mathrm{J})$ or $(\mathrm{N}-\mathrm{m})$ & Btu \\
\hline Gravitational Acceleration (g) & $9.8066 \mathrm{~m} / \mathrm{s}^{2}$ & $32.1739 \mathrm{ft} / \mathrm{s}^{2}$ \\
\hline Density $(\rho)$ & $\mathrm{Kg} / \mathrm{m}^{3}$ & $\mathrm{lbm} / \mathrm{ft}^{3}$ \\
\hline Velocity (v) & $\mathrm{m} / \mathrm{s}$ & $\mathrm{ft} / \mathrm{s}$ \\
\hline Pressure (P) & $\operatorname{Pascal}\left(\mathrm{N} / \mathrm{m}^{2}\right)$ & $\mathrm{lbf} / \mathrm{in}^{2}$ \\
\hline Dynamic Viscosity $(\mu)$ & Pascal-s (Kg/m-s) & $\mathrm{lbm} / \mathrm{ft}-\mathrm{s}$ \\
\hline Kinematic Viscosity $(v)$ & $\mathrm{m}^{2} / \mathrm{s}$ & $\mathrm{ft}^{2} / \mathrm{s}$ \\
\hline Specific Heat (Cp) & $\mathrm{J} / \mathrm{Kg}-{ }^{\circ} \mathrm{K}$ & $\mathrm{Btu} / \mathrm{lbm}-{ }^{\circ} \mathrm{F}$ \\
\hline Power (Q) & Watt $(W)$ or $(\mathrm{J} / \mathrm{s})$ & Btu/hr \\
\hline Heat Flux & $\mathrm{J} / \mathrm{m}^{2}-\mathrm{s}$ & $\mathrm{Btu} / \mathrm{ft}^{2}-\mathrm{hr}$ \\
\hline Volumetric Heat Source & $\mathrm{J} / \mathrm{m}^{3}-\mathrm{s}$ & $\mathrm{Btu} / \mathrm{ft}^{3}-\mathrm{hr}$ \\
\hline Heat Transfer Coefficient $\left(h_{c}\right)$ & $\mathrm{J} / \mathrm{m}^{2}-\mathrm{s}-\mathrm{O} \mathrm{K}$ & $\mathrm{Btu} / \mathrm{ft}^{2}-\mathrm{hr}-{ }^{\circ} \mathrm{F}$ \\
\hline Thermal Conductivity (k) & $\mathrm{J} / \mathrm{m}-\mathrm{s}^{\circ}{ }^{0} \mathrm{~K}$ & Btu/ft-hr- ${ }^{\circ} \mathrm{F}$ \\
\hline Thermal Diffusivity $(\alpha)$ & $\mathrm{m}^{2} / \mathrm{s}$ & $\mathrm{ft}^{2} / \mathrm{s}$ \\
\hline Mass Diffusivity & $\mathrm{m}^{2} / \mathrm{s}$ & $\mathrm{ft}^{2} / \mathrm{s}$ \\
\hline Volume Expansion Coefficient $(\beta)$ & $1 / \% \mathrm{~K}$ & $1 \% \mathrm{R}$ \\
\hline Surface Reaction Rate (mass units) & $\mathrm{Kg} / \mathrm{m}^{2}-\mathrm{s}$ & $1 \mathrm{bm} / \mathrm{ft}^{2}-\mathrm{s}$ \\
\hline Volumetric Reaction Rate (mass units) & $\mathrm{Kg} / \mathrm{m}^{3}-\mathrm{s}$ & $1 \mathrm{bm} / \mathrm{ft}^{3}-\mathrm{s}$ \\
\hline Heat of Reaction (mass units) & $\mathrm{J} / \mathrm{Kg}$ & Btw/lbm \\
\hline Gravitational Constant $\left(\mathrm{g}_{\mathrm{c}}\right.$ ) & $1 \mathrm{Kg}-\mathrm{m} / \mathrm{N}-\mathrm{s}^{2}$ & $32.174 \mathrm{lbm}-\mathrm{f} / / \mathrm{bf}-\mathrm{s}^{2}$ \\
\hline Stefan-Boltzman Constant $(\sigma)$ & $5.6697 \mathrm{E}-8 \mathrm{~J} / \mathrm{s}-\mathrm{m}^{2}-{ }^{\circ} \mathrm{K}^{4}$ & $1.714 \mathrm{E}-9 \mathrm{Btw} / \mathrm{hr}-\mathrm{ft}^{2}-{ }^{\circ} \mathrm{R}^{4}$ \\
\hline Universal Gas Constant $\left(\mathrm{R}_{\mathrm{u}}\right)$ & $8314.34 \mathrm{~J} / \mathrm{Kgmole}-{ }^{\circ} \mathrm{K}$ & $1545 \mathrm{ft}-1 \mathrm{bm} / \mathrm{lbm}-\mathrm{mole}-{ }^{\circ} \mathrm{F}$ \\
\hline
\end{tabular}


HNF-3830, Rev. 0

\subsection{INTRODUCTION}

\subsection{Purpose and Objective}

The purpose of this report is to document the results of a series of analyses that were performed to assess the thermal-hydraulic performance of the concrete plutonium storage cubicles, as modified for the horizontal placement of plutonium storage canisters. The goal of these analyses was to determine the peak concrete and component temperatures during nominal steady-state operations for various ventilation flow rates and inlet temperatures, as well as the peak transient temperatures associated with a postulated loss-of-forced ventilation flow (LOFF) event. The analyses focused on a single concrete storage cubicle with maximum decay heat. These analyses are expected to provide general guidance on the feasibility of using the existing, but modified concrete storage cubicles with a "new" plutonium storage container design.

The primary objectives of this effort were; 1 ) develop the necessary thermal-hydraulic models to evaluate the nominal steady-state and transient temperature distributions for the modified storage cubicles, and 2) support the definitive design, provide design recommendations, and support the safety analysis report.

\subsection{Background}

A change to the current vault packaging configuration has been initiated based on the Department of Energy standard; DOE-STD-3013-96. The new standard permits a "new" storage container for the packaging and long term storage of Special Nuclear Material (SNM), such as plutonium oxide $\left(\mathrm{PuO}_{2}\right)$ powder. The "new" plutonium storage containers are commonly referred to as either the 3013 containers or 3013 canisters.

Current plans call for the current inventory of plutonium at Hanford to be stored in the 3013 containers. The current concrete storage vaults must be modified to support and safely store the 3013 canisters. Criticality considerations limit the number of 3013 containers per cubicle to 22 . The 3013 containers will be positioned horizontally in two vertical columns of 11 for a total decay heat load of 330 Watts per cubicle or a maximum of 15 watts per canister. Therefore, the maximum decay heat load for one storage vault containing modified storage cubicles is 22.44 KW.

\subsection{Content}

Section 2.0 provides a brief summary of the analysis results and conclusions. Section 3.0 discusses the computer program that was used to perform the analyses. Section 4.0 provides a physical description of the storage cubicle, 3013 containers, and the storage vault. Section 4.0 also provides a discussion of the thermal-hydraulic models that were developed for the analyses, as well as the assumptions that were made. Section 5.0 presents the results of the analyses. Section 6.0 summarizes the results and conclusions. Section 7.0 provides the references. 


\subsection{EXECUTIVE SUMMARY}

Given horizontal 3013 canister storage, four separate models were developed for the thermal assessment of the modified concrete plutonium storage cubicles. This was necessary to handle the change in dimensional scales ranging from the full height concrete storage cubicles to the relatively thin walls and small separation distances among the three containers that comprise a 3013 canister. The thermal-hydraulic models increase in detail and complexity as the dimensional scale decreases.

The goal of these analyses was to determine the peak concrete and component temperatures during nominal steady-state operations for various ventilation flow rates and inlet temperatures, as well as the peak transient temperatures associated with a postulated loss-of-forced ventilation flow (LOFF) event. The analyses focused on a single concrete storage cubicle with maximum decay heat. These analyses are expected to provide general guidance on the feasibility of using the existing, but modified concrete storage cubicles with horizontal placement of 3013 canisters.

NOTE:The subject thermal analyses are considered conceptual and must be reviewed for applicability prior to implementing horizontal storage of 3013 canisters. Any revisions to the current design concept, technical bases, and assumptions, as documented within this report, may require additional thermal analyses to demonstrate compliance with peak concrete temperatures.

The following conclusions are made:

1. The nominal peak concrete temperatures are expected to be less than $150^{\circ} \mathrm{F}$ during steadystate operations. Peak concrete temperatures range between $144^{\circ} \mathrm{F}$ and $148^{\circ} \mathrm{F}$ for the range of Case 3 conditions shown in Table 3 . This is very close to maximum value of $150^{\circ} \mathrm{F}$, as recommended by the American Concrete Institute $(\mathrm{ACl})$ for normal operations or any other long term period. However, the results are based on a series of conservative assumptions that are not expected to simultaneously occur within any one cubicle.

2. The peak concrete temperatures during a Loss-Of-Forced Flow (LOFF) event will exceed 200 ${ }^{\circ} \mathrm{F}$ within approximately 8 hours.

3. Uncertainties in the cubicle flow rate, inlet temperature, and canister heat loads could result in nominal steady-state peak concrete temperatures greater than $150^{\circ} \mathrm{F}$. These uncertainties can result from the following;

- Bypass or leakage flow through the various edge, lap, and upper gaps surrounding the front concret doors

- Inlet temperature variations due to seasonal or building heat loads

- Canister heat loads greater than 15 watts due to the buildup of Americium-241 and other high order decay isotopes. 
The following recommendations are offered:

1. Center the 3013 canisters front-to-rear with approximately 0.75 inch gaps between the rear liner plate and front concrete door. Small tabs projecting from the supporting straps are recommended as stops. It is recommended that the 3013 canister not be allowed to touch either the front door or the rear liner plate as this would provide a conduction path to remove the energy from the canister and would create a hot spot.

2. Seal all door edge, lap, and upper gaps with high temperature radiation resistant metal tape. (Do not seal the lower 1.5 by 24 inch gap under the door.) This will prevent flow from bypassing the canister columns and possibly increasing the peak concrete temperatures.

3. Remove as much as possible of the old vertical support racks and canister shelves. The thermal-hydraulic models assumed that there was little or no flow resistance due to the remaining structure.

4. Vault inlet ventilation air temperatures must not exceed $82^{\circ} \mathrm{F}$. This is based on the small margins to a peak concrete temperature of $150^{\circ} \mathrm{F}$ from the Case $3 \mathrm{~A}(9 \mathrm{X})$ analysis summarized in Table 4.

5. The maximum initial heat load of the 3013 canisters must include sufficient margin to 15 watts to accommodate the buildup of high decay heat isotopes such as Americium-241.

6. Emergency response procedures must reflect a requirement to restore nominal vault flow within eight hours.

7. Although not explicitly required for the analyses documented within this report, the thermal conductivity data for plutonium oxide is extremely sparse. Current measurements have large uncertainties for oxide powder densities less than $6.0 \mathrm{gm} / \mathrm{cm}^{3}$. Additional thermal conductivity data is required for $\mathrm{PuO}_{2}$ versus temperature and powder densities less than 6.0 $\mathrm{gm} / \mathrm{cm}^{3}$ for various fill gases (i.e., air, helium, and argon). It is recommended that a laboratory program be established to provide measured values of thermal conductivity for plutonium oxide powder. It is anticipated that such a program will help refine the thermal assessments for the 3013 canisters during future conversion, long term storage, or transportation activities. 
HNF-3830, Rev. 0

\subsection{CODE DESCRIPTION}

The Fluid Dynamic Analysis Package (FIDAP) computer program was used to develop the thermal-hydraulic models of the 3013 canisters and concrete storage cubicles and to perform the analyses. FIDAP has been validated and verified for use at Hanford (Heard 1994) for the performance of quality affecting analyses.

FIDAP is a commercially available general purpose computer package that uses finite element methods (FEM) to simulate many classes of single or multi-phase compressible or incompressible flows, including heat transfer, and mass transport of chemical species $(<15)$ in both nonreacting and reacting flows. The simulation can be either steady-state or transient and can model flows in complex arbitrary geometries that are 2-D, axi-symmetric, or 3-D. Mixed coordinate or moving/rotating systems are supported.

FIDAP can be thought of as a single environment for the simulation of thermal-hydraulic problems and can be viewed as an integrated set of components and program modules designed to perform all aspects of model generation, automatic meshing, or paving, problem setup including view factor calculations, solving the resulting matrix of simultaneous finite element forms of the equations for the conservation of momentum, mass, and energy, and post-processing (i.e., visualizing) the results. The post processing capabilities of FDAP are considered one of the industries best.

FDAP is currently active on a Silicon Graphics Power Indigo-2, with an R-10000 CPU, $256 \mathrm{Mb}$ of main system memory, running under the IRIX 6.2 operating system with FORTRAN 77 Version 7.0. The IRIX 6.2 operating system uses a 64 -bit real and integer single precision wordlength (128-bit double precision).

FIDAP is a registered trademark of Fluid Dynamics, Inc., Evanston, I11 inois. 


\subsection{MODEL DEVELOPMENT, ANALYSIS METHODOLOGY, AND ASSUMPTIONS}

Four separate models were developed for the thermal assessment of the modified concrete plutonium storage cubicles with horizontal 3013 canisters. This was necessary to handle the change in dimensional scales ranging from the full height concrete storage cubicles to the relatively thin walls and small separation distances among the three containers within the 3013 canister. The thermal-hydraulic models increase in detail and complexity as the dimensional scale decreases.

Of the four models developed, only the full height storage cubicle and axi-symmetric (RZ) 3013 canister models were used during the subject analyses. The remaining two detailed models of a horizontal 3013 canister were developed for use at a later date, but are discussed in the following paragraphs for completeness.

\subsection{Description of Storage Cubicles, Storage Vault, and 3013 Canisters}

Figures $1 \mathrm{~A}$ and $1 \mathrm{~B}$ present representative isometric and floor plan view, respectively, of a $2736 \mathrm{Z}$ building vault with cubicles. It must be emphasized that Figure $1 \mathrm{~A}$ is not to scale and is not meant to represent the actual dimensions or design details associated with the storage cubicles. Figure $1 \mathrm{~A}$ presents a conceptual overview of a vault with concrete storage cubicles that was analyzed and documented by this report.

There are 68 cubicles per vault located side-to-side and back-to-back in three parallel rows and two single rows against the north and south walis of the vault. Each storage cubicle is eight feet high by 32 inches wide by two feet deep ( 96 inches x 32 inches x 24 inches). The cubicle walls are eight inches thick, with two overlapping hinged concrete doors on the front of each cubicle. The internal storage space is one-by-two-by-eight feet. Each storage cubicle can contain a maximum of 223013 canisters. (See Fluor Daniel Northwest, Inc., Drawing H-2-829374, Rev. A, "Canister Support Rack Sections and Details. ) The 3013 canisters are arranged in two vertical columns with 11 canisters per column. The 3013 canisters are positioned horizontally using a square array with a pitch of 8.25 inches.

Supply air is provided to each cubicle via a 1.5-by-24 inch gap located at the bottom of each set of doors. (The total vault volumetric flow of $1500 \mathrm{cfm}$ at $80^{\circ} \mathrm{F}$ or $22.06 \mathrm{cfm}$ per storage cubicle is assumed to be distributed equally.) The exhaust flow is received by a continuous ventilation duct mounted above each cubicle. The ventilation duct collects the individual flow from each cubicle along each of the eight rows. The eight ventilation ducts tie into one vault common exhaust header. The exhaust header from each of the four vaults eventually merge and are discharged to the atmosphere after passing through a set of HEPA (High Efficiency Particulate Air) filters. 
Figure 2 presents an isometric view of a single concrete storage cubicle with 3013 canisters. Figures 3 through 5 present elevation, section and plan views of a storage cubicle, respectively, including the horizontal storage racks.

The 3013 canister consists of, including the convenience can lid, three nested containers; an outer, inner, and convenience can. The 3013 container components were assumed to be fabricated from stainless steel 316 and assembled, as presented in Figure 6.

Figure 7 presents a cross sectional view of an assembled 3013 canister. The dimensions were obtained from British Nuclear Fuels Laboratory (BFNL) drawing number OBE-1555424. The dimensions, as shown in Figure 7, were derived assuming the two inner cans are vertically centered within the outer can and resting on each other. No contact resistances were input for the interfaces between the bottom surfaces of the convenience, inner, and outer cans. Each of three cans is slightly larger than the preceding inner can. The wall thicknesses range from a maximum of $3 \mathrm{~mm}$ ( 0.118 inches) for the outer can, $1.5 \mathrm{~mm}$ (0.059 inches) for the inner can, and $1.0 \mathrm{~mm}$ ( 0.039 inches) for the innermost convenience can. The convenience can has a screw top lid with a metal seal ring. The outer two containers have upper lids attached to the cylindrical body by a welded seal. The two radial gaps are $1.0 \mathrm{~mm}(0.03937)$ inches. The upper air gaps range from approximately $4 \mathrm{~mm}$ ( 0.157 inches) to approximately $8 \mathrm{~mm}$ (0.315 inches).

The innermost convenience can is assumed to contain a porous low density mixture of $\mathrm{PuO}_{2}$ and dry air. For a given mass loading, the density of the $\mathrm{PuO}_{2}$ will affect the fill level within the innermost container. Criticality safety specifications limit the total mass loading for each 3013 canister to $5 \mathrm{Kg}$ of plutonium oxide or $4.4 \mathrm{Kg}$ of plutonium. Five kilograms of plutonium oxide at $2.735 \mathrm{gm} / \mathrm{cm}^{3}$ will completely fill the convenience can. If the average density is greater than $2.735 \mathrm{gm} / \mathrm{cm}^{3}$, the convenience can will not be completely full, but still could contain $5 \mathrm{Kg}$. Figure 8 illustrates the user determined a variable height interface between the plutonium oxide and dry air filled void space for a vertically orientated 3013 canister. Figure 9 presents possible plutonium oxide configurations for a horizontal 3013 canister.

\subsection{Steady-State Model Development}

The thermal-hydraulic models that were developed are discussed in the following sections.

\subsubsection{Full Height Storage Cubicle Model}

Figure 10 presents an elevation view of a full height storage cubicle with a top mounted ventilation duct. Figure 10 illustrates the two-dimensional (side-to-side) model that was developed and reflects the repeating side-to-side and symmetrical front-to-back cubicle arrangement within the vault. Figure 10 is considered representative of a storage cubicle located within an interior row with other storage cubicles each with the same identical number of 3013 containers and total decay heat. The left hand and right side concrete walls were modeled as four inches. This represents half of the total wall thickness of eight inches between adjacent cubicles. 
The solid front concrete doors and rear concrete wall could not be modeled in this particular twodimensional model. The left and right-hand side concrete boundaries were designated as adiabatic (i.e., no heat flow allowed across the boundary).

All three modes of energy transfer (i.e., conduction, convection, and radiation) were allowed within the boundaries of the above model. Energy is removed from the storage cubicle by convective heat transfer given air flow up through and across the top of each cubicle. A convective heat transfer coefficient was also applied to the upper external surface of the duct to account for losses through the thin sheet metal to the vault ambient temperature of $80^{\circ} \mathrm{F}$ $\left(26.9^{\circ} \mathrm{C}\right)$. Losses to the vault basepad and the ground below the vault were not modeled.

This model was used to complete a series of steady-state and transient thermal-hydraulic analyses to determine the flow distribution within the cubicle and around the containers, as well as the temperature distributions within the storage cubicle.

Because, of practical limits imposed by the dimensional scales involved and limited system memory, only the outermost container was modeled as a separate component. The inner two canisters, gaps, and plutonium were modeled as a smeared mass with a volumetric heat generation heat equivalent to 15 watts.

\subsubsection{Unit Cell Models}

The unit cell models were developed to simulate a single 3013 canister positioned horizontally within the storage cubicle at a given elevation. These models are more detailed that the full storage cubicle model.

\subsubsection{Side-To-Side (XY)}

The single 3013 canister model, shown in Figure 11, was developed to refine the concrete temperatures and to determine the asymmetrical temperature distribution around the 3013 canister at a given elevation. The location and spacing of the 3013 canister within this model is consistent with 223013 canisters horizontally positioned within a square array with a pitch of 8.25 inches. The left-hand side of the concrete wall is modeled as an adiabatic surface. The right-hand side is the centerline to the storage cubicle and is modeled with the appropriate velocity boundary conditions. Energy is removed from the 3013 canister by convective and radiative heat transfer.

Each of the three containers is modeled as separate component oriented horizontally with a line of contact between. The inter-container gaps are shown and, for illustration purposes only, an arbitrary plutonium oxide fill level is shown within the innermost container. The decay heat of the plutonium oxide is assumed to be 15 watts. 


\subsubsection{Detailed Stand Alone 3013 Canister Model}

A detailed thermal model was developed to simulate a single 3013 canister laying on its side. As shown in Figure 12, this model is a very detailed representation of a 3013 canister with a user determined fill height for the plutonium oxide. The surrounding flow field is not calculated, but is accounted for by either applying a heat transfer coefficient or a fixed temperature to the outermost surface. This model runs very fast and only solves the conservation of energy equation. Typically, the outer surface temperature or heat transfer coefficients are derived from the thermal-hydraulic models discussed in Section 4.2 .1 or 4.2.2.1.

\subsubsection{Front-To-Back (RZ)}

The final thermal model that was developed is referred to as the front-to-back or RZ model and is shown in Figure 13. This model was developed to determine the temperature distribution within a closed storage cubicle. Specifically, the peak concrete temperatures for the front door and back walls were of interest. The back liner ( 0.1875 inches), 3013 canister, and the various air gaps were modeled. The two air gaps on either end of the 3013 canister are variable depending on user input and could vary from 0.125 inches to 1.4375 inches. This was used to simulate the horizontal placement of a 3013 canister anywhere within the support rack. A zero gap distance was not modeled given a 3 degree upward tilt of the placement straps. The air gap between the back wall and liner was assumed to remain fixed at 0.375 inches. The left hand or rear concrete wall was modeled as four inches, given the eight inch thick walls between adjacent cubicles. The right-hand side or front concrete door was modeled as eight inches. The left-hand side or rear concrete wall was designated as adiabatic (i.e., no heat flow allowed across the boundary). The details associated with the internal component to the 3013 canister were not modeled; rather, the internals were modeled as a smeared mass with a volumetric heat generation rate consistent with 15 watts.

As in Section 4.2.2.2, the flow fields were not modeled, but were accounted for by the application of various heat transfer coefficients to the appropriate surfaces. In particular, heat transfer via convective and radiative means was allowed from the front and rear surfaces of the concrete door and liner, as the outer surface of the 3013 canister and rear concrete. The vault ambient temperature was assume to be $80^{\circ} \mathrm{F}$. The boundary condition associated with the internal air was assumed to be equal to the maximum outlet air temperature of $128.5^{\circ} \mathrm{F}$ obtained from the results of the full height storage cubicle, as discussed in Section 6.1.1.

\subsection{Transient Model Development}

The transient model was developed from the same thermal-hydraulic models that were discussed in Sections 4.1 and 4.2, but required three additional steps to complete.

The first step consisted of determining the ambient air temperatures within the vault surrounding the storage cubicles versus time after a complete loss-of-forced-flow. This information was 
manually programmed into FIDAP for determining convective and radiative heat transfer. This portion of the LOFF analysis utilized a previously developed whole building model (Heard 1997) including the HVAC system within the $2736 \mathrm{Z}$ building and assumed a constant $115^{\circ} \mathrm{F}$ external environmental temperature. Figure 14 presents the ambient air temperature within the vault versus time during a simulated loss-of-forced flow event. The initial ambient air temperature is $80^{\circ} \mathrm{F}$. The final ambient air temperature is $118.2^{\circ} \mathrm{F}$. Appendix $\mathrm{A}$ lists the three user subroutines that were developed to supply the time varying vault air temperatures (USRINI), calculate the reference temperature (USRREF), and calculate the convective heat transfer coefficient (USRCNV).

The second and third parts consisted of using the predicted average vault air temperature versus time from the whole building model, as boundary conditions to the full height (XY) and front-torear (RZ) storage cubicle models. The LOFF analyses were initiated from steady-state temperature distributions representative of normal operations.

The results of the transient LOFF analyses are presented in Section 6.2. 
HNF-3830, Rev. 0

Figure 1A.

Representative View of a Storage Vault.

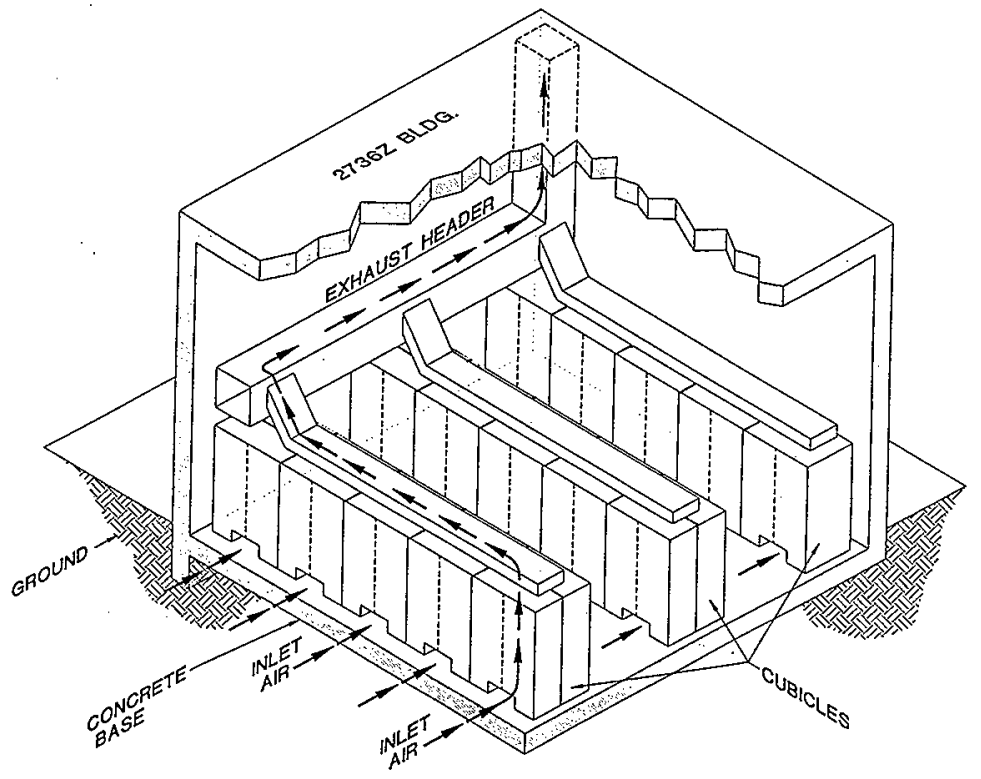


HNF-3830, Rev. 0

Figure 1B.

Floor Plan View of a Storage Vault.

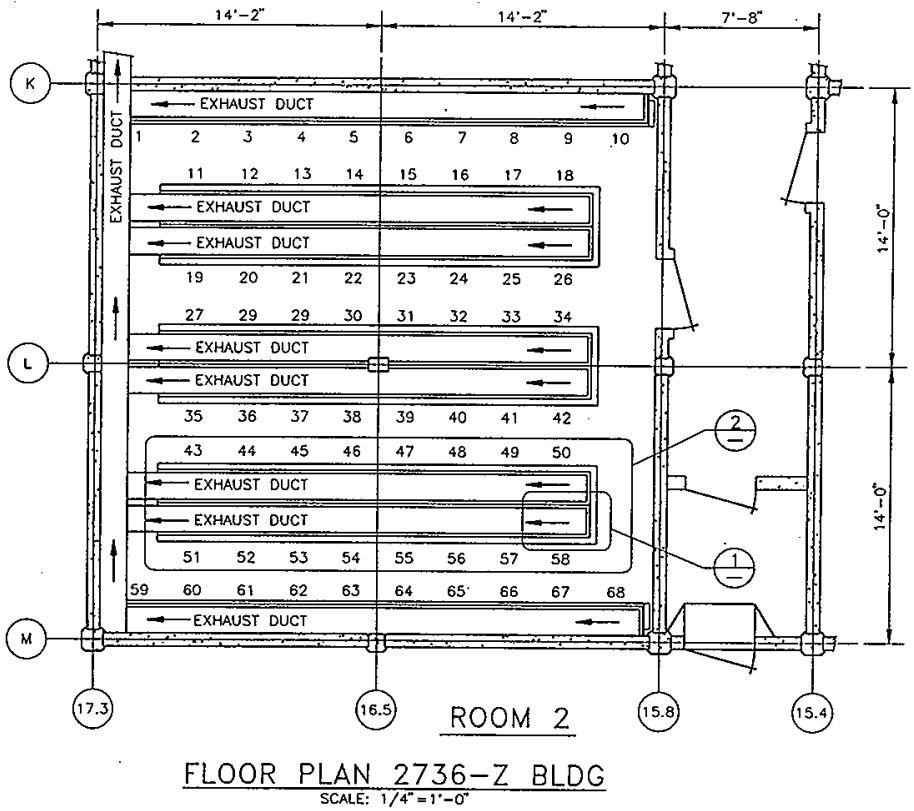


HNF-3830, Rev. 0

Figure 2.

Isometric View of Storage Cubicle, 3013 Canister, and Ventilation Duct.

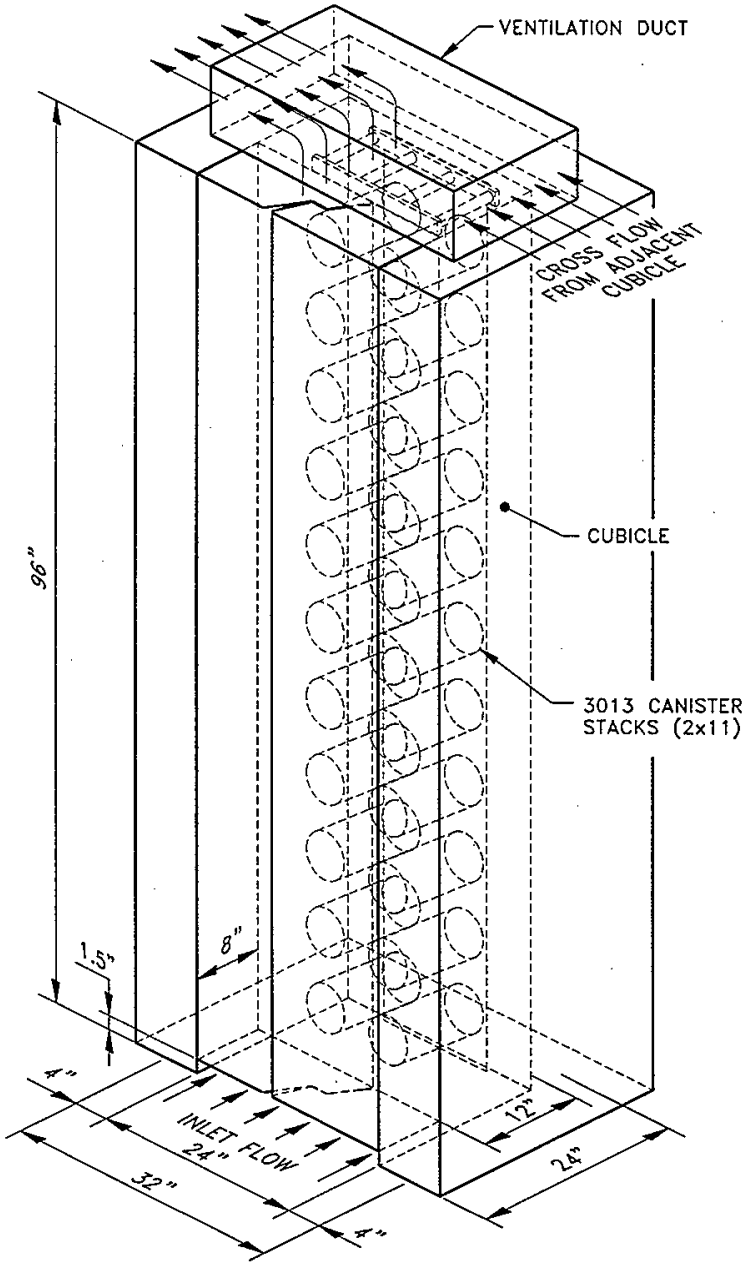


HNF-3830, Rev. 0

Figure 3.

Elevation View of 3013 Canister Support Rack.

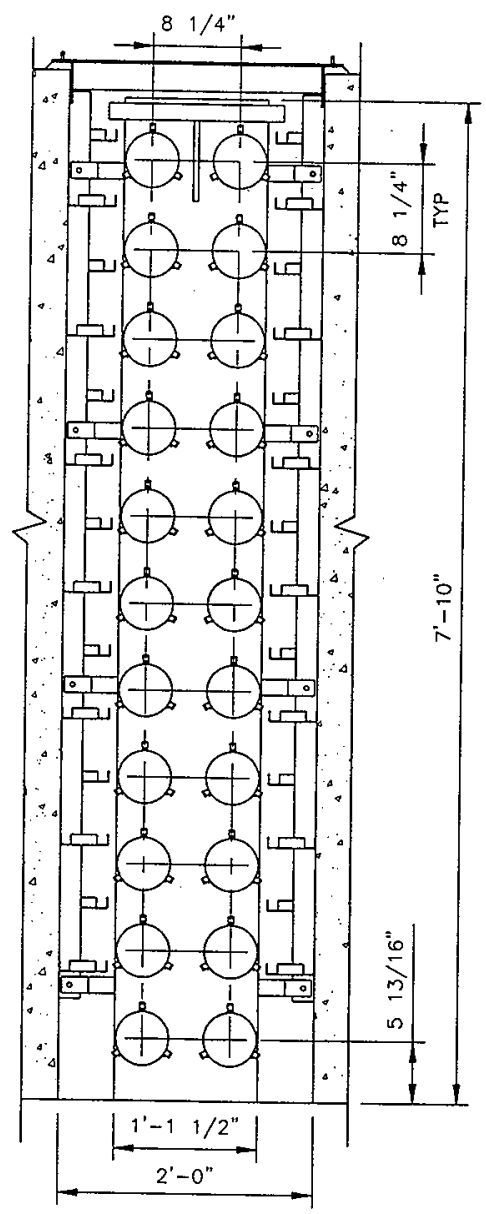


HNF-3830, Rev. 0

Figure 4.

Section View of 3013 Canister Support Rack.

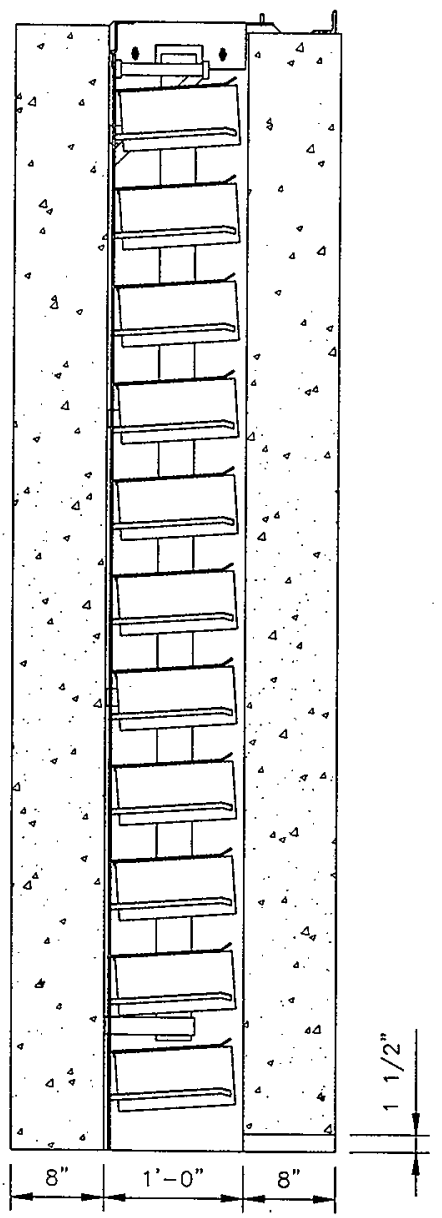


HNF-3830, Rev. 0

Figure 5.

Plan View of 3013 Canister Support Rack.

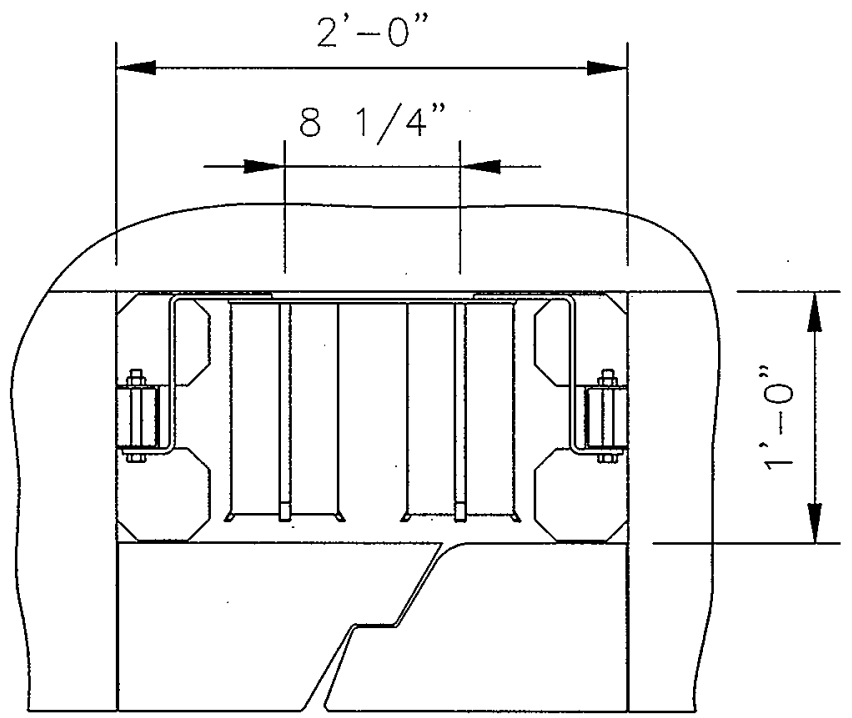


HNF-3830, Rev. 0

Figure 6.

Final Assembly Sequence of 3013 Canister.

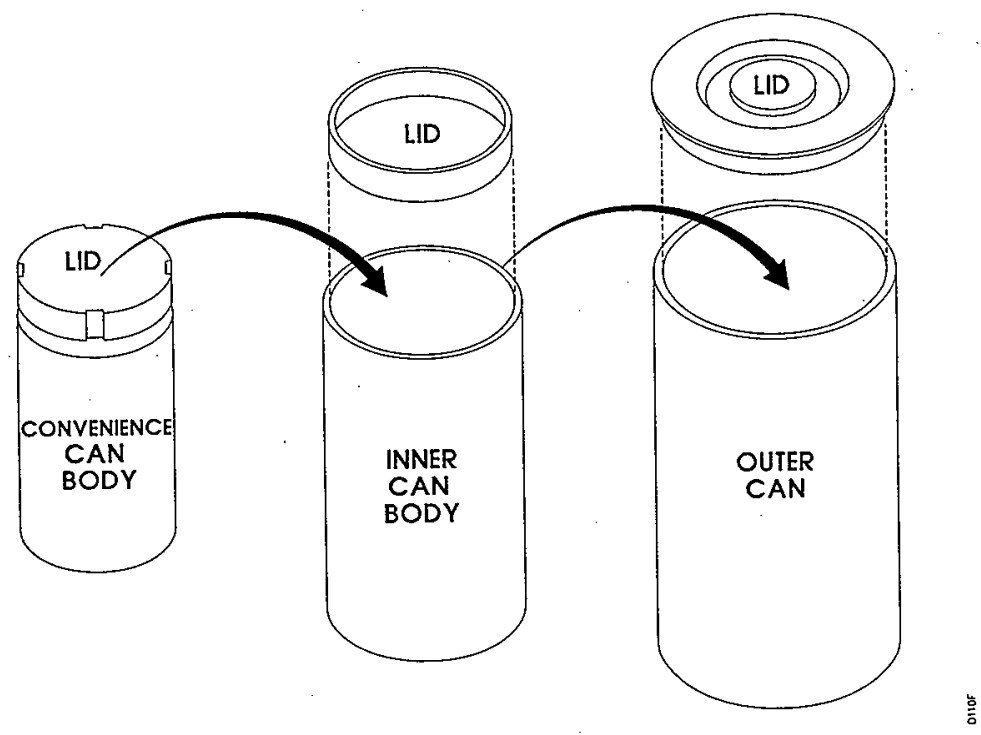


HNF-3830, Rev. 0

Figure 7.

Section View of a Vertical 3013 Canister.

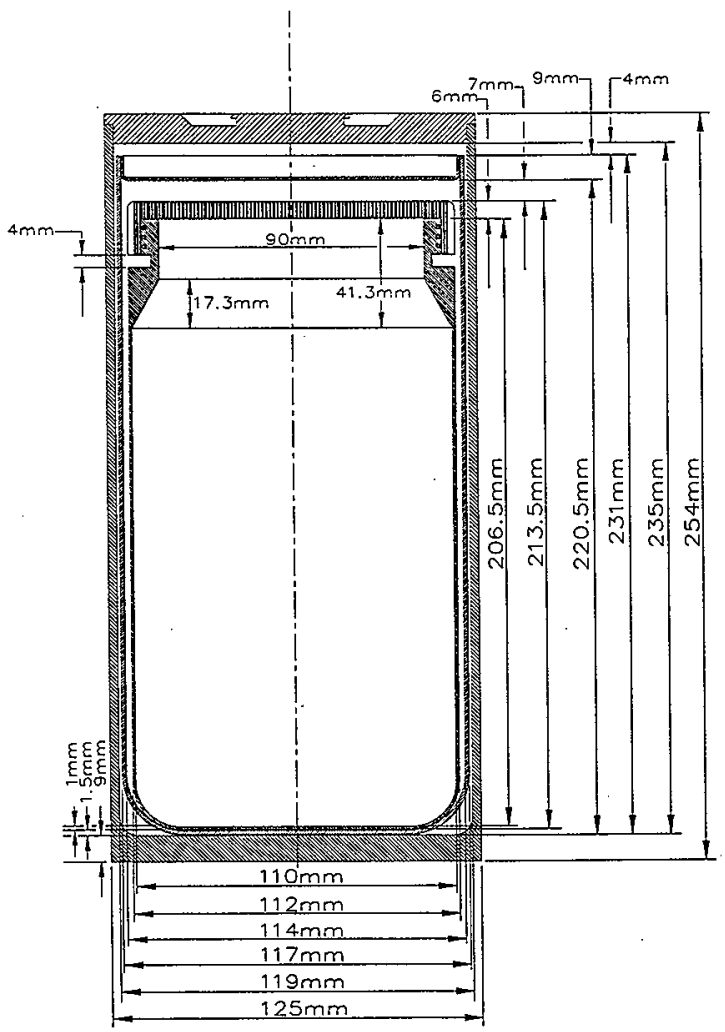

ธิ 
HNF-3830, Rev. 0

Figure 8.

$\mathrm{PuO}_{2}$ Powder Level Within a Vertical 3013 Canister.

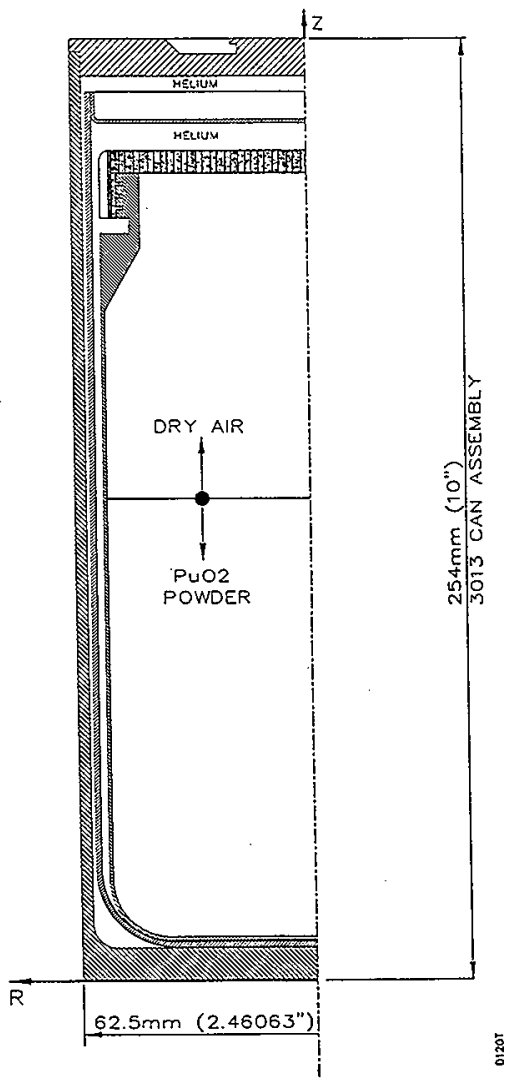




\section{HNF-3830, Rev. 0}

Figure 9.

Possible $\mathrm{PuO}_{2}$ Powder Configurations Within a Horizontal 3013 Canister.
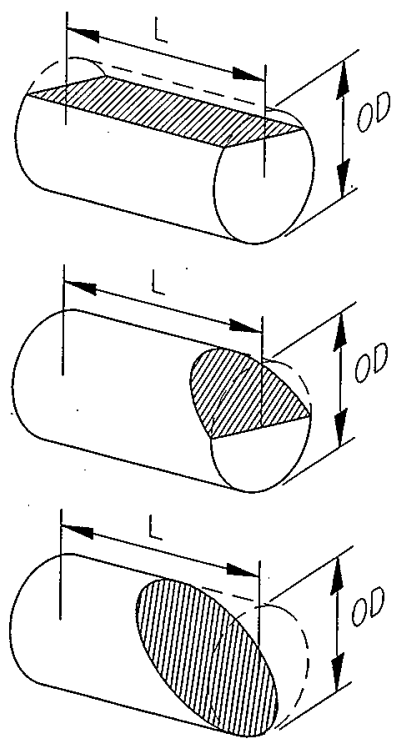
HNF-3830, Rev. 0

Figure 10.

Thermal Model of a Full Height Storage Cubicle.

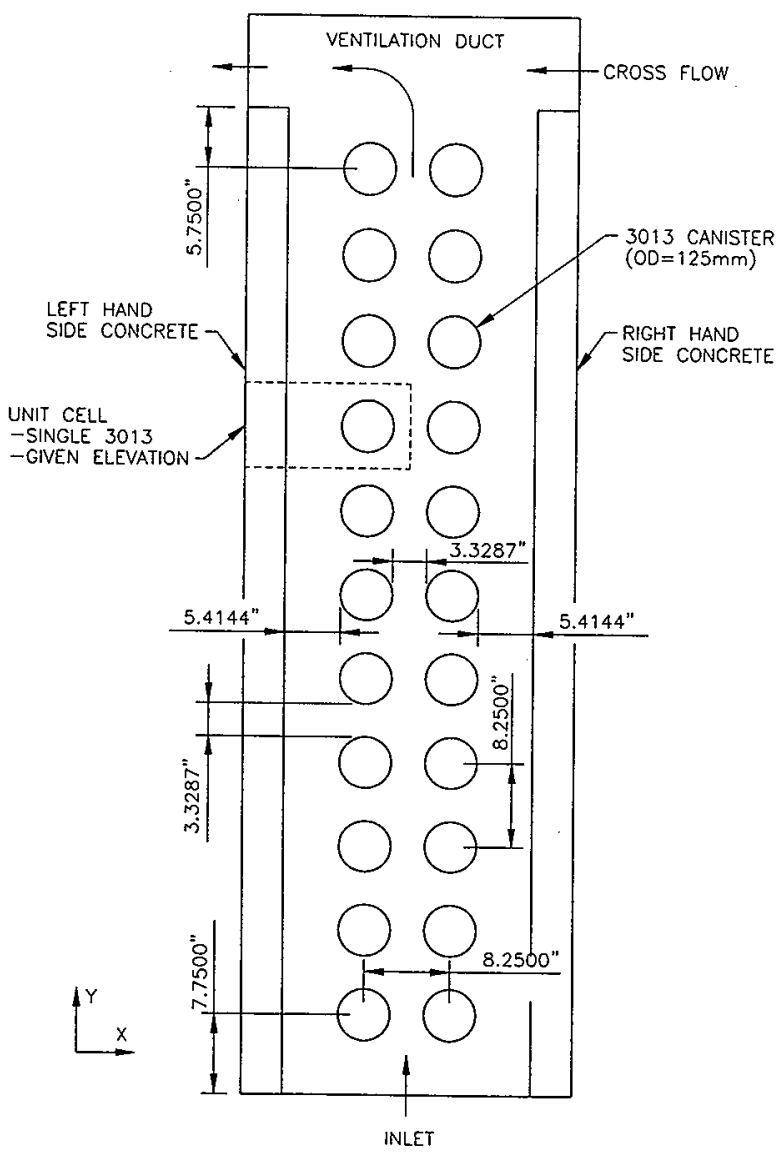




\section{HNF-3830, Rev. 0}

Figure 11.

Thermal Model of a Single 3013 Canister Within a Storage Cubicle at a Given Elevation.

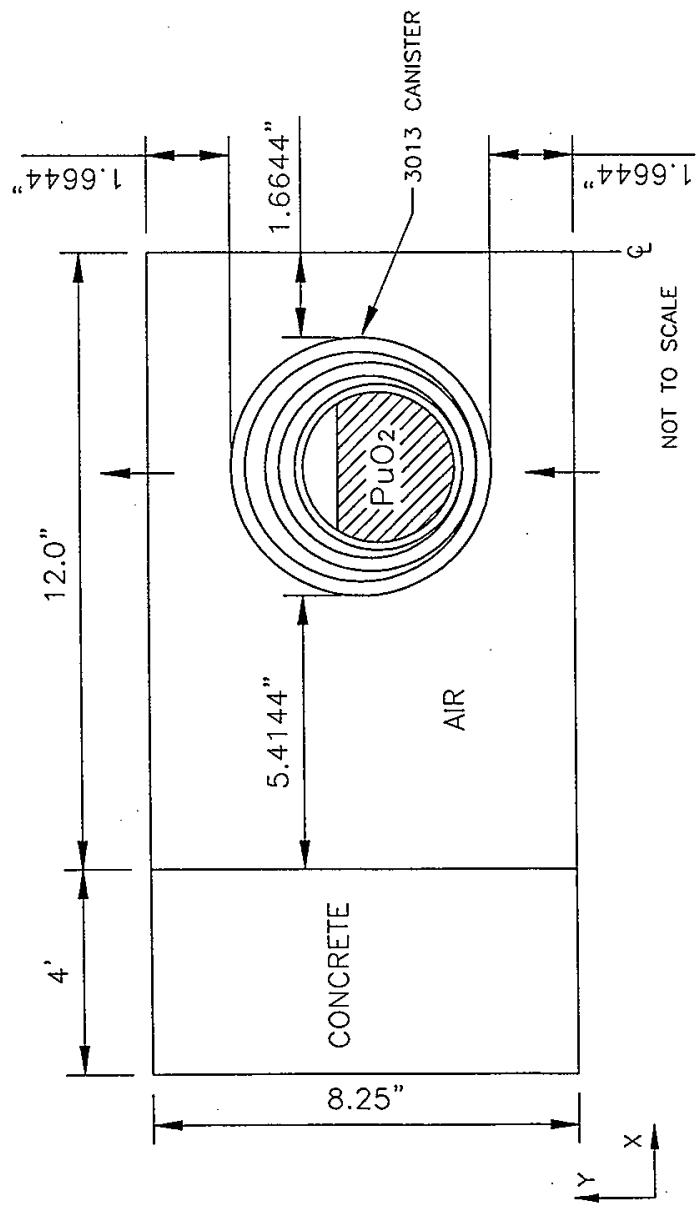


HNF-3830, Rev. 0

Figure 12.

Thermal Model of a Single Standalone 3013 Canister.

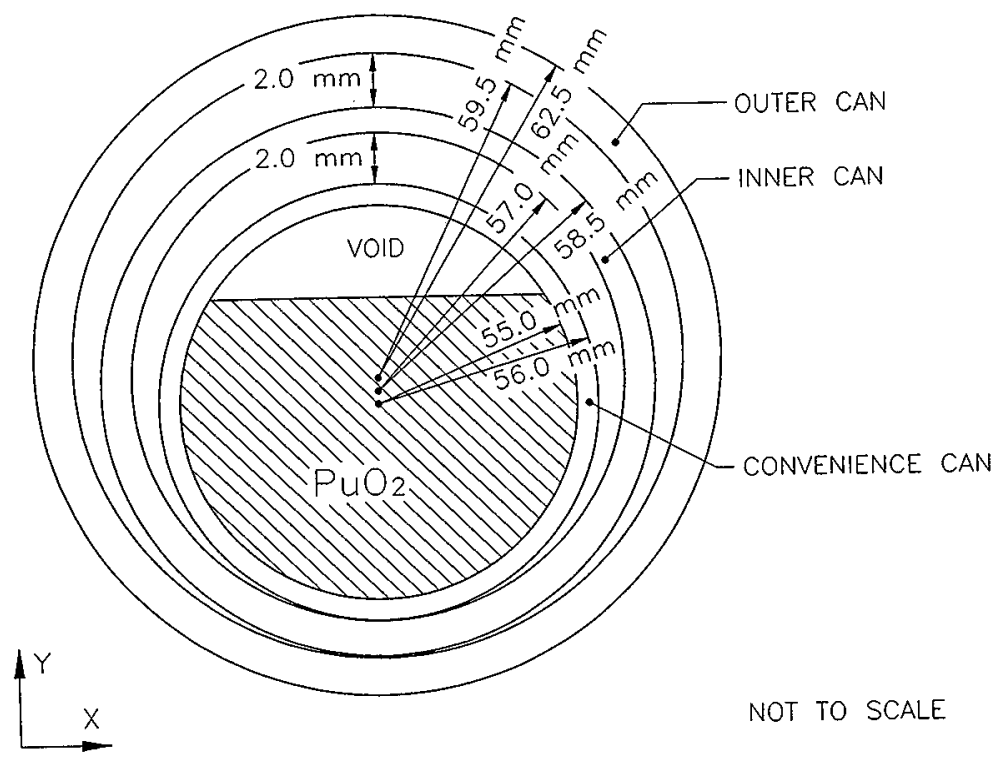


HNF-3830, Rev. 0

Figure 13.

Axi-Symmetric Thermal Model of a Single Horizontal 3013 Canister Within a Storage Cubicle at a Given Elevation.

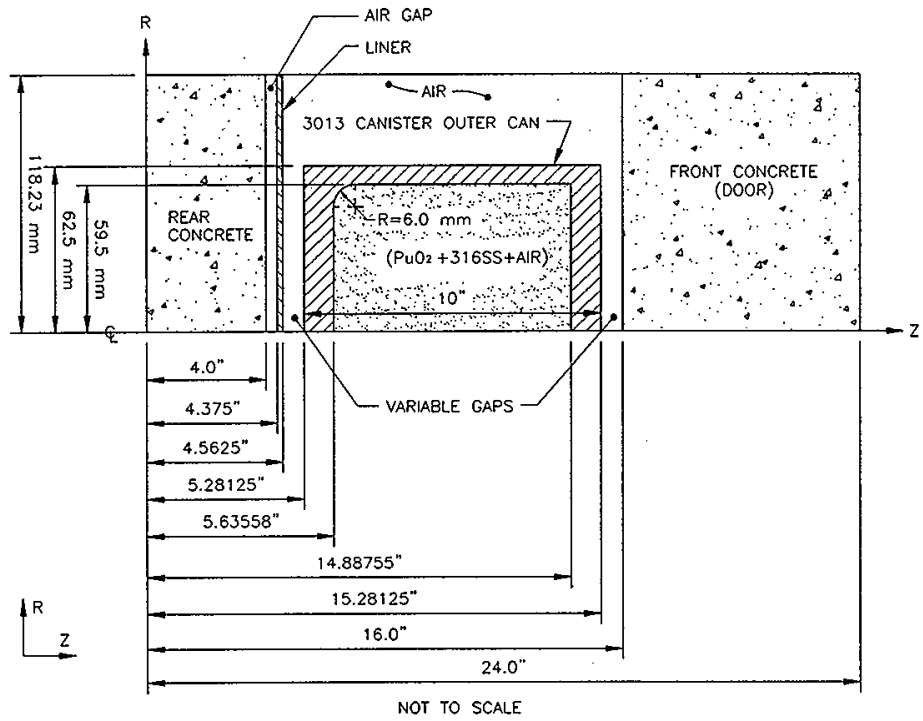


HNF-3830, Rev. 0

Figure 14.

Ambient Air Temperatures Within Storage Vault Versus Time During a Simulated Loss-Of-Forced Flow Event.

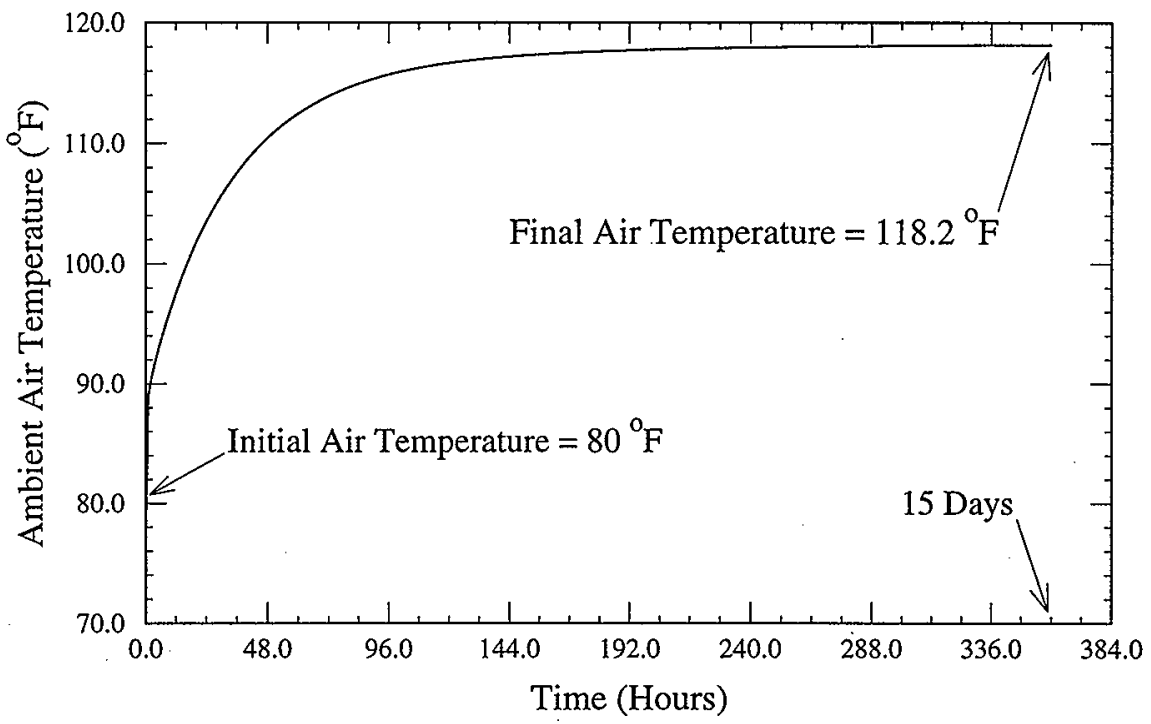




\subsection{TECHNICAL BASES AND ASSUMPTIONS}

The basic geometry of the thermal-hydraulic models used for the analyses is discussed in Section 4.0. The following sections discuss the convective heat transfer correlations, the modeling limitations, and assumptions that were used for the analyses.

\subsection{Convective Heat Transfer}

Convective heat transfer from external surfaces exposed to flow fields can be explicitly calculated by performing a coupled thermal-hydraulic analysis or applied via heat transfer coefficients obtained from known correlations. The application of a heat transfer coefficient derived from a correlation usually requires a known ambient temperature.

The heat transfer correlations are different for vertical and horizontal surfaces and are different for laminar and turbulent flows. For horizontal surfaces the correlations are different if the surface faces up or down and is heated or cooled.

The convective heat transfer coefficients are based on Nusselt $(\mathrm{Nu})$ numbers derived from correlations which are dependent on air properties, the calculated film temperature, and known geometrical characteristics. The convective heat transfer coefficients are in turn derived by setting the Nusselt number equal to $h_{c}{ }^{*} L / k_{f}$ and solving for $h_{c}$. This formulation is discussed further in the following paragraphs. For additional information on convective heat transfer coefficients readers are referred to Chapter 7 of HOLMAN 1990.

The convective heat transfer coefficients that were derived for to the storage cubicle model were applied to the external surfaces consisting of vertical flat plates and horizontal flat plates facing upwards heated from below where the surrounding flow patterns were not calculated. The convective heat transfer for the internal regions of the storage cubicle, duct, and outer diameter of the 3013 containers were explicitly calculated.

For the standalone 3013 container model convective heat transfer coefficients were not applied. Rather the peak surface temperature of a given 3013 canister or an average heat transfer coefficient as obtained from the storage cubicle model was applied to the external surface of the 3013 container model.

Convective heat transfer internal to the 3013 canister was not modeled. The internal gaps between the outer and inner containers were assumed to be small enough to prevent the formulation of convective cells. Only conduction and radiation were allowed.

In general, the convective heat transfer correlations can be represented in the following functional form for a variety of conditions:

$$
\mathrm{Nu}_{\mathrm{f}}=\mathrm{C} *\left(\mathrm{Gr}_{\mathrm{f}} * \mathrm{Pr}_{\mathrm{f}}\right)^{\mathrm{m}}
$$


Where the constants $\mathrm{C}$ and $\mathrm{m}$ are specified in Table 7-1 of HOLMAN 1990 and summarized in Table 1 for a variety of geometries and a range of Rayleigh numbers. The product of the Grashof (Gr) and Prandtl numbers is called the Rayleigh ( $\mathrm{Ra}$ ) number. The subscript $f$ indicates that the air properties in the dimensionaless groups are evaluated at a film temperature defined as:

$$
\mathrm{T}_{\mathrm{f}}=\left(\mathrm{T}_{\mathrm{amb}}+\mathrm{T}_{\text {wall }}\right) / 2
$$

The Grashof number may be physically interpreted as a dimensionaless value representing the ratio between the buoyancy and viscous forces in a natural or "free" convection flow system. The Grashof number consists of a variety of terms as shown;

$$
\mathrm{Gr}=\mathrm{g}^{*} \rho^{2 *} \beta^{*} \Delta \mathrm{T} * \mathrm{~L}^{3} / \mu^{2}
$$

Where, $\quad g=$ gravitational acceleration constant, $9.8 \mathrm{~m} / \mathrm{s}^{2}$

$\rho=$ density $\left(\mathrm{kg} / \mathrm{m}^{3}\right)$

$\beta=$ the coefficient of expansion $\left(1 /{ }^{\circ} \mathrm{K}\right)$, which for an ideal gas is the inverse of the absolute temperature

$\Delta \mathrm{T}=$ absolute temperature difference between the calculated wall and ambient air temperature $\left({ }^{\circ} \mathrm{K}\right)$

$\mathrm{L}=$ characteristic length $(\mathrm{m})$

$\mu=$ viscosity $(\mathrm{kg} / \mathrm{m}-\mathrm{s})$

The Prandtl number has been found to be the parameter which relates the relative thicknesses of the hydrodynamic and thermal boundary layers and may be interpreted physically as the ratio between the rate momentum and heat diffuse through the fluid. Most gases and liquids have Prandtl numbers near 0.7. The Prandtl number consists of several terms as shown;

$$
\operatorname{Pr}=C_{p} * \mu / k
$$

Where, $\quad \mathrm{C}_{\mathrm{p}}=$ Specific heat $\left(\mathrm{J} / \mathrm{kg}^{-}{ }^{\circ} \mathrm{K}\right)$

$\mathrm{k}=$ thermal conductivity $\left(\mathrm{J} / \mathrm{s}-\mathrm{m}-{ }^{\circ} \mathrm{K}\right)$, and

$\mu=$ viscosity $(\mathrm{kg} / \mathrm{m}-\mathrm{s})$

The heat transfer coefficient can then be derived knowing that the Nusselt $(\mathrm{Nu})$ number is actually defined as follows:

$$
\mathrm{Nu}_{\mathrm{f}}=\mathrm{h}_{\mathrm{c}} * \mathrm{~L} / \mathrm{k}_{\mathrm{f}}
$$

reạranging yields,

$$
\mathrm{h}_{\mathrm{c}}=\mathrm{Nu}_{\mathrm{f}}^{*} \mathrm{k}_{\mathrm{f}} / \mathrm{L}
$$


where, $h_{c}$ is the heat transfer coefficient $\left(\mathrm{J} / \mathrm{s}-\mathrm{m}^{2}-{ }^{\circ} \mathrm{K}\right), \mathrm{k}_{\mathrm{f}}$ is the thermal conductivity of air evaluated at the film temperature, and $\mathrm{L}$ is the characteristic dimension of the particular geometry.

The correlations used for the analyses were obtained from (Holman 1990) and are summarized in Table 1. Appendix A presents a listing of the three user subroutines (i.e., USRCNV, USRINI, USRREF) that were written to revaluate the heat transfer coefficient used during the LOFF. analyses. Appendix B summarizes the material properties for air, concrete, medium carbon steel, soil, stainless steel 316 , and plutonium oxide

\subsection{Modeling Limitations}

No energy transfer was allowed across the left and right-hand side concrete walls. This reflects the conservative assumptions that the subject storage cubicle is "surrounded" on both sides by storage cubicles at the same identical conditions. The basepad and ground were not explicitly modeled. No energy losses to the basepad or ground were allowed. The later is an acceptable assumption for steady-state conditions, since the inlet flow will effectively keep the basepad and lower region of the storage cubicle near inlet conditions and is considered a conservative treatment for restricting energy losses during a simulated loss-of-forced-flow event.

The temperatures of the upper surfaces of the storage cubicle, including the cross ventilation duct on top of the storage cubicle, were not constrained and were allowed to "float" subject to convective and radiative energy losses to the ambient vault temperature. The derivation of the convective heat transfer coefficients that were used for the upper duct surface is discussed in Section 5.1

The flow fields external to the storage cubicle were not modeled. Air flow is assumed to be result from flow entering each storage cubicle under the concrete doors and up through the cubicle, and either across the top from the cubicles to the exhaust header.

For the cross duct ventilation model the inlet velocity was fixed and was based on a volumetric flow rate of $22.0588 \mathrm{CFM}$ per cubicle at $80^{\circ} \mathrm{F}$. This corresponds to a total vault flow of 1500 $\mathrm{cfm}$ distributed equally to all storage cubicles. The analysis assume that the entire $22.0588 \mathrm{cfm}$ is available as upward flow through the canister columns. No bypass flow due to small gaps around the door edges or center lap joint is assumed. The inlet velocity through the ventilation duct on top of the cubicle was based on the volumetric flow rate associated with one and nine downstream cubicles, and therefore, represents the range from minimum to maximum velocity. Both hand calculations and code output were used for the verification of flow areas, inlet and cross flow velocities, volumetric flow rates, mass flow rates, and mass fluxes.

The mixed mean outlet temperature from the cubicle columins was conservatively estimated to be no greater than $128.5^{\circ} \mathrm{F}$, assuming $100 \%$ of the decay heat was deposited within the air. 
For the unit cell models, dry air was assumed within the small diametrical gaps among the 3013 containers. The thermal conductivity of the Plutonium oxide was assumed to be based on a mixture of plutonium oxide and dry air.

The 3013 canisters were assumed to have a total power of 15 Watts $(\mathrm{J} / \mathrm{s})$ uniformiy distributed throughout the entire oxide $\left(\mathrm{PuO}_{2}\right)$ powder volume.

The density of the plutonium oxide powder was assumed to be $2.5 \mathrm{gm} / \mathrm{cm}^{3}$. From previous work, the density of the plutonium oxide powder will vary from 6.0 to $1.5 \mathrm{gm} / \mathrm{cm}^{3}$. For plutonium oxide powders with a densities greater than $2.735 \mathrm{gm} / \mathrm{cm}^{3}$, the $5 \mathrm{Kg}$ load limit will be reached with fill volumes less than the convenience can's maximum volume of $1828 \mathrm{~cm}^{3}$. The greater the density the smaller the fill volume necessary to obtain $5 \mathrm{Kg}$. For the subject analyses, the innermost convenience can is assumed to be completely filled with a porous $2.5 \mathrm{gm} / \mathrm{cm}^{3}$ mixture of $\mathrm{PuO}_{2}$ and dry air.

The thermal conductivity of $\mathrm{PuO}_{2}$ powder in air as a function of powder density was obtained from experimentally determined data, as documented within Jerrell 1994. A least squares fit to this data was used to derive a functional relationship for calculating the thermal conductivity of $\mathrm{PuO}_{2}$ versus powder density at intervening points. Table 2 presents a listing of the thermal conductivities that were used for the subject analyses. Figure 15 graphically presents the measured and interpolated $\mathrm{PuO}_{2}$ data that were used for the subject analyses. The thermal conductivity of $\mathrm{PuO}_{2}$ was assumed to be constant over the range of temperatures calculated by these analyses for a given powder density.

Energy transfer internal to 3013 canister models was allowed via a combination of conduction and thermal radiation, but not convection. Convective losses were not allowed given that the internal gaps are small enough to prevent the formation of convective cells. The fill gas (dry air) is assumed to be stagnant. This is very similar to a double pane thermal-window where the small gap prevents the development of convective cells by interfering with the growth of the boundary layers on the facing surfaces.

The standalone 3013 canister thermal model required only that the conservation of energy equation be solved. Solving the conservation of momentum and mass equations are not necessary, since the flow fields around the 3013 canister within the storage cubicle were already simulated and the convective losses from the 3013 canister could be explicitly determined.

\subsection{Miscellaneous Assumptions}

The following paragraphs summarize the various technical bases (i.e., givens) and assumptions that were made for the subject thermal-hydraulic analyses. 
1. The 3013 can components, including the convenience can lid, were assumed to be fabricated from stainless steel 316 and assembled, as shown in Figure 6. The 3013 container dimensions were obtained from BNFL Drawing OBE 1555424 dated July 1996. Once sealed the 3013 containers were positioned horizontally, as shown in Figure 12.

2. Dry air was assumed within the small diametrical gaps between the two outer cans and external to the 3013 containers.

3. The total decay heat of 15 Watts was assumed to be uniformly distributed throughout the entire plutonium oxide $\left(\mathrm{PuO}_{2}\right)$ powder volume. The decay heat was assumed entirely from the decay of the various plutonium isotopes.

4. The thermal conductivity of $\mathrm{PuO}_{2}$ powder in air as a function of powder density was obtained from experimentally determined data, as documented within Jerrell 1994. Table 2 and Figure 15, respectively, present a listing and graphical representation of the thermal conductivities that were used for the subject analyses.

5. The heat capacity $(\rho \mathrm{Cp})$ for $\mathrm{PuO}_{2}$ was derived assuming the appropriate oxide powder density multiplied by the temperature dependent specific heat obtained from Table 7.70 of Katz 1990.

6 No contact resistances were modeled between the 3013 components. In addition, no contact resistance was modeled between the $\mathrm{PuO}_{2}$ powder and the inner can.

7. Radiative heat transfer was modeled from the upper concrete surfaces, duct walls, interior concrete surfaces, and the outer can surface of the 3013 containers. A 3013 canister surface emissivity $(\epsilon=0.25)$ corresponding to bright brushed stainless steel was assumed for all the 3013 container surfaces and was obtained from Appendix D of Siegel 1992. The surface emissivity of concrete was assumed to be 0.75 . A surface emissivity approaching 0.95 for concrete is possible for a very rough dark finish. However, most if not all of the concrete surfaces are painted with a dark grey paint with a semi-smooth finish. Surface emissivity can be significantly affected by paint. The assumed surface emissivity of 0.75 is considered to be a conservative value.

8. The material properties ( $k, \rho$, and $\mathrm{Cp}$ ) for dry air, stainless steel 316 and Concrete were obtained from Irwin 1993 and Short 1995. Appendix B presents a summary listing of the various materials and properties.

9. The axi-symmetric (RZ) thermal model was assumed for the thermal-hydraulic 3013 container analyses; where the line of symmetry corresponds to the centerline of the 3013 can(s). It is assumed that the variation of all variables with respect to the theta $(\theta)$ direction is identically zero. 
HNF-3830, Rev. 0

10. The steady-state thermal-hydraulic analyses were performed assuming average ambient temperatures corresponding to nominal conditions expected to occur during normal forced flow conditions. The ambient temperature was assumed to be $80^{\circ} \mathrm{F}$ for vault volumetric flow rate of $1500 \mathrm{cfm}$.

11. The LOFF analyses assumed that the initial steady-state ambient air temperature for the storage vault was $80^{\circ} \mathrm{F}$. The atmospheric temperature was assumed to be a constant 115 ${ }^{\circ} \mathrm{F}$. The corresponding steady-state forced flow patterns and temperature distributions within a storage cubicle, including the concrete were calculated and used as the initial conditions for the LOFF analysis. 
HNF-3830, Rev. 0

Table 1

Constants for Use with Empirical Correlations

for Natural Convection Heat Transfer Coefficient

$\left(\mathrm{Nu}=\mathrm{C}^{*}\left(\mathrm{Gr}_{\mathrm{f}}^{*} \mathrm{Pr}_{\mathrm{f}}\right)^{\mathrm{m}}\right)$

\begin{tabular}{|c|c|c|c|c|}
\hline Geometry & $\operatorname{Ra}_{f}=G r_{f} * \mathrm{Pr}_{f}$ & C & $\mathrm{m}$ & Comments \\
\hline $\begin{array}{l}\text { Vertical Planes } \\
\text { and Cylinders }\end{array}$ & $\begin{array}{c}10^{4} \cdot 10^{9} \\
10^{9} \cdot 10^{13}\end{array}$ & $\begin{array}{l}0.59 \\
0.10\end{array}$ & $\begin{array}{l}1 / 4 \\
1 / 3\end{array}$ & Laminar + Turbulent \\
\hline $\begin{array}{l}\text { Upper Horizonal } \\
\text { Surface of Heated } \\
\text { Plates or Lower } \\
\text { Surface of Cooled } \\
\text { Plates }\end{array}$ & $\begin{array}{c}2 \times 10^{4}-8 \times 10^{6} \\
8 \times 10^{6}-10^{11}\end{array}$ & $\begin{array}{l}0.54 \\
0.15\end{array}$ & $\begin{array}{l}1 / 4 \\
1 / 3\end{array}$ & $\begin{array}{c}\text { Laminar } \\
\text { Laminar + TurbuTent }\end{array}$ \\
\hline $\begin{array}{l}\text { Lower Horizontal } \\
\text { Surface of Heated } \\
\text { Plates or Upper } \\
\text { Surface of Cooled } \\
\text { Plates }\end{array}$ & $10^{5}-10^{11}$ & 0.27 & $1 / 4$ & Laminar + Turbulent \\
\hline
\end{tabular}

More complicated relations (improved) relationships have been developed over wide ranges of Rayleigh Numbers;

$\overline{\mathrm{Nu}}=0.68+\frac{0.670 \mathrm{Raf}^{1 / 4}}{\left(1+(0.492 / \mathrm{Pr})^{9 / 16}\right)^{4 / 9}} ;$ for $\mathrm{Raf}_{\mathrm{f}}<10^{9}$

or

$\overline{\mathrm{Nu}} \mathrm{u}^{1 / 2}=0.825+\frac{0.0387 \mathrm{Raf}^{1 / 6}}{\left(1+(0.492 / \mathrm{Pr})^{9 / 16}\right)^{8 / 27}} ;$ for $10^{-1}<\operatorname{Raf}<10^{12}$ 
HNF-3830, Rev. 0

Table 2

Thermal Conductivity for $\mathrm{PuO}_{2}$ Powder Versus Density.

\begin{tabular}{|c|c|c|}
\hline $\begin{array}{c}\mathrm{PuO}_{2} \\
\left(\mathrm{gm} / \mathrm{cm}^{3}\right)\end{array}$ & $\begin{array}{c}\text { SI Units } \\
\left(\mathrm{J} / \mathrm{m}-\mathrm{s}-{ }^{\circ} \mathrm{K}\right)\end{array}$ & $\begin{array}{c}\text { Engl ish Units } \\
\left.\text { (Btu/ft-hr }{ }^{\circ} \mathrm{F}\right)\end{array}$ \\
\hline 6.0 & 2.1267 & 1.2288 \\
\hline 5.5 & 1.8374 & 1.0617 \\
\hline 5.0 & 1.5482 & 0.8946 \\
\hline 4.5 & 1.2590 & 0.7275 \\
\hline 4.0 & 0.9698 & 0.5604 \\
\hline 3.5 & 0.6805 & 0.3932 \\
\hline 3.0 & 0.3913 & 0.2261 \\
\hline 2.735 & 0.3334 & 0.1937 \\
\hline 2.5 & 0.2824 & 0.1632 \\
\hline 2.0 & 0.1737 & 0.1004 \\
\hline 1.5 & 0.0692 & 0.0400 \\
\hline
\end{tabular}




\section{HNF-3830, Rev. 0}

Figure 15

Thermal Conductivity of Plutonium Oxide in Dry Air Versus Density

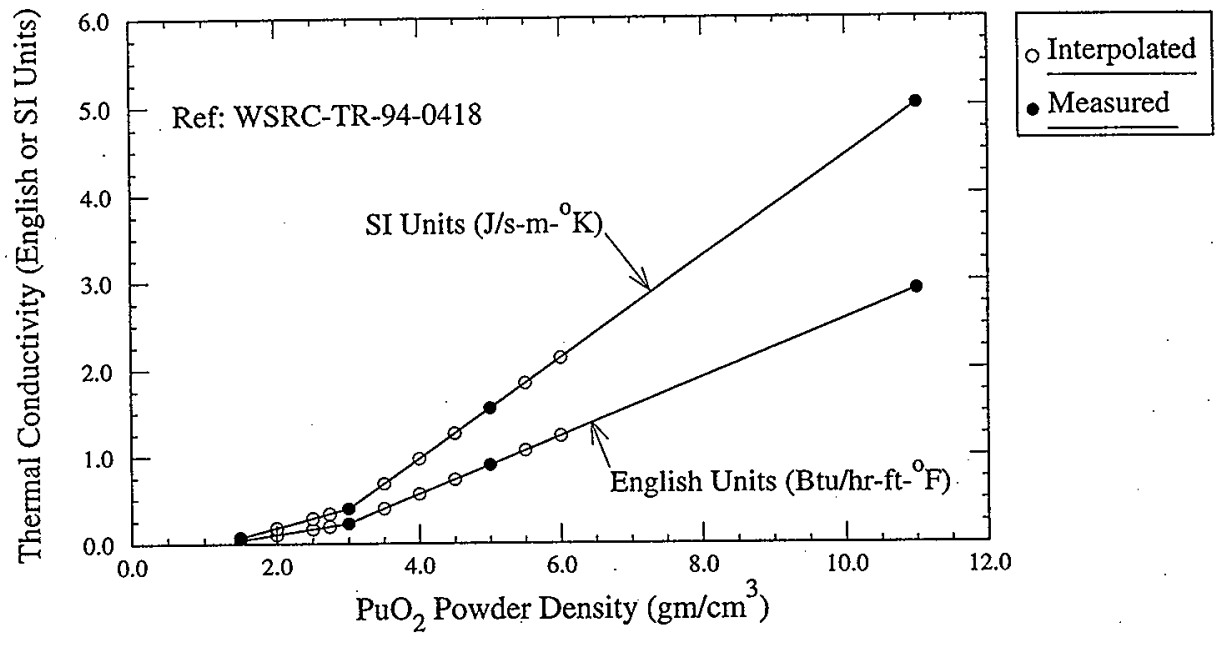


HNF-3830, Rev. 0

\subsection{RESULTS}

The results of the steady-state and transient thermal-hydraulic analyses for the modified storage cubicle with horizontal 3013 containers are presented in the following Sections. Section 6.1 presents the results of the steady-state analyses. Section 6.2 presents the results of the transient Loss-Of-Forced-Flow (LOFF) analyses. The emphasis of the following sections is on concrete temperatures and focuses on a single concrete storage cubicle with maximum decay heat.

\subsection{Steady State}

A storage cubicle with 22 horizontally positioned 3013 convenience cans was evaluated for steady-state temperatures given different combinations of reference conditions. Table 3 summarizes the conditions that were assumed for the forced flow analyses. Note that the outlet temperature was calculated using material properties associated with the inlet temperature.

The results of the steady-state storage cubicle analyses are presented in Section 6.1.1. Section 6.1.2 presents the standalone 3013 container thermal analyses.

\subsubsection{Full Height}

Table 4 presents the results of the forced flow analyses that were obtained for the full height storage cubicles. The peak concrete temperatures range from $108.4^{\circ} \mathrm{F}\left(315.6^{\circ} \mathrm{K}\right)$ to $148.3^{\circ} \mathrm{F}$ $\left(337.8^{\circ} \mathrm{K}\right)$ depending on the flow rate, inlet temperature, and total heat load. The maximum concrete temperatures are associated with Cases $3 \mathrm{~A}$ and $3 \mathrm{~B}$. Cases $3 \mathrm{~A}$ and $3 \mathrm{~B}$ assume a total vault flow rate of $1500 \mathrm{~cm}$ ( $22.059 \mathrm{cfm}$ per cubicle), a storage cubicle inlet vault air temperature of $80^{\circ} \mathrm{F}\left(300^{\circ} \mathrm{K}\right)$, and a cubicle total heat load 330 Watts (15 watts per canister). Case $3 \mathrm{~A}$ and $3 \mathrm{~B}$ differ in the magnitude of the cross flow velocity through the upper ventilation duct. The range in concrete temperatures between Case $3 \mathrm{~A}$ and Case $3 \mathrm{~B}$ is representative of the nominal conditions expected for the modified storage vaults positioned along a given row of cubicles within the storage vault. The following discussion focuses on the results obtained for the Case $3 \mathrm{~A}$ and $3 \mathrm{~B}$ conditions.

Figure 16 presents the overall storage cubicle temperature distribution for Case $3 \mathrm{~A}(1 \mathrm{X})$ conditions. Figure 17 presents an enlarged view of the temperature distribution for a block of six 3013 canisters near the top of the storage cubicle for Case $3 \mathrm{~A}$. The heated air plume is clearly noticeable exiting the columns of 3013 canisters. Figure 18 presents a line plot of the temperatures across the top of the columns from left to right. The thermal plumes from each of the two parallel columns of 3013 canisters are clearly shown. Figure 19 presents the temperature distribution within the left and right-hand side concrete walls. Figures 20 and 21 present line plots illustrating the temperatures in degrees Kelvin along the inside surface of the right-hand concrete wall from the lower basepad to the top of the storage cubicle for Cases $3 \mathrm{~A}$ and $3 \mathrm{~B}$, respectively. Both Figures 19 and 20 show some very minor fluctuations in the concrete surface 
temperatures due to radiative heating from the 3013 canisters. From Figure 21, the maximum concrete temperature was $148.3^{\circ} \mathrm{F}\left(337.8^{\circ} \mathrm{K}\right)$ and is located near the $1.58 \mathrm{~m}(5.18 \mathrm{ft}$.) level.

The surface temperatures of the 3013 containers range from values near the inlet temperature of $80.3^{\circ} \mathrm{F}\left(300.0^{\circ} \mathrm{K}\right)$ to a maximum value of $182.8^{\circ} \mathrm{F}\left(356.9^{\circ} \mathrm{K}\right)$, depending on elevation. As shown in Figure 22, temperature variations up to approximately 4 to $5^{\circ} \mathrm{K}\left(7\right.$ to $\left.9^{\circ} \mathrm{F}\right)$ were noticed around the outermost container with the peak temperature usually found on the upper portion of each of the 3013 containers. This is attributed to reduced flows between the canisters.

Figure 23 presents a representative view of the velocity vectors (i.e., flow velocities) at the outlet from the storage cubicle for a cross flow velocity of $1 \mathrm{X}$. Note the large recirculation cell in the outlet leg of the cross duct. This is due the sharp corner associated with the interior surface of the left-hand side concrete wall. If this corner was rounded, with a 2-inch radius, the downstream recirculation cell would be minimized and may actually help to reduce flow resistance and improve the overall flow characteristics through the cubicles. Crossflow velocities of $1 \mathrm{X}$ correspond to a storage cubicle one position inboard from the end farthest away from the exhaust header. A crossflow velocity of $9 \mathrm{x}$ corresponds to a storage cubicle nearest the exhaust header. Table 4 indicates that the magnitude of the cross flow has a small affect on the maximum concrete temperature within the storage cubicle.

\subsubsection{Axi-Symmetric}

Table 5 presents the peak concrete temperatures versus the 3013 canister axial position within a storage cubicle at various reference conditions. A maximum concrete temperature of $141.1^{\circ} \mathrm{F}$ $(333.8 \mathrm{~K}$ ) is indicated for a minimum front gap at Case $3 \mathrm{~A}$ conditions. Table 5 is analogous to Table 4, but was derived based on an axi-symmetric (RZ)(Front-to-Back) thermal model (see Figure 13) of a 3013 canisters at a given elevation within a storage cubicle.

The axi-symmetric (RZ) Front-To-Rear thermal model was developed with a user adjustable gap. The model is able to accommodate a 3013 canister located at different axial positions within a storage cubicle. The minimum gap was assumed to be 0.125 inches and the maximum gap was assumed to be 1.3175 inches. These dimensions were chosen based on the minimum and maximum gaps that could occur given dimensional tolerances and the 3 degree upward tilt for the 3013 canister holding straps. No flow fields were modeled. However, the axi-symmetric model did utilize air temperatures and heat transfer coefficients consistent with the outlet conditions obtained by the uppermost 3013 containers within the storage cubicle. The convective heat transfer coefficients were derived for these conditions were applied to the external surface of the 3013 canister and the various vertical interior surfaces associated with the front concrete and liner. A surface emissivivity of 0.25 was assumed for the 3013 canister and liner. A surface emissivity of 0.75 was assumed for the various concrete surfaces. The axi-symmetric (Front-toRear) 3013 canister model appears to accurately reflect the peak conditions expected during steady-state operations as simulated by the full height $(\mathrm{XY})$ storage cubicle model. 
Figure 24 presents the temperature $\left({ }^{\circ} \mathrm{K}\right)$ contours associated with the axi-symmetric thermal model for a minimum ( 0.125 inches) front gap at Case $3 \mathrm{~A}$ conditions. A minimum front gap maximizes the local (front door) concrete temperatures directly opposite the 3013 canister. The peak concrete temperature is $141.1 \mathrm{~F}(333.8 \mathrm{~K})$. This is consistent with Table 2, which showed similar concrete temperatures with a peak value near $144 \mathrm{~F}$ for the same Case $3 \mathrm{~A}(1 \mathrm{X})$ conditions from Table 4. Figure 25 presents an enlarged view of the front third of the RZ model. The temperature $\left({ }^{\circ} \mathrm{K}\right.$ ) contours near the front gap (Contour labels $\mathrm{E}, \mathrm{F}, \mathrm{G}$, and $\mathrm{H}$ ) are shown with more resolution. Figure 26 presents a line plot of the interior surface temperatures for the front concrete structure for the minimum gap at Case $3 \mathrm{~A}$ outlet conditions versus radial distance from the centerline of the model. Peak concrete temperatures are obtained on the centerline directly opposite the 3013 canister.

The concrete temperature decreases with increasing distance away from the 3013 canister as convective and radiative cooling occurs from the vertical concrete surface. From Table 5, temperatures of the back or rear concrete are lower and show some, but relatively minor temperature changes as the gaps are adjusted. This is due to the liner plate. The liner plate acts as a thermal shield and limits the peak temperature of the concrete behind the 3013 canister to a maximum of $133.3 \mathrm{~F}(329.4 \mathrm{~K})$, but also tends to keep the back concrete at a more uniform temperature.

\subsection{Transient-Loss-of-Forced-Flow (LOFF)}

A full building model of the $2736 \mathrm{Z}$ storage vaults was previously developed to perform a loss-offorced flow (LOFF) analysis for the proposed In-Floor Storage Vault (Heard 1997). The maximum decay heat heat load for one vault containing the modified storage cubicles is 22.44 $\mathrm{kW}$ (i.e., $15 \times 22 \times 68$ ). The LOFF event was analyzed for a simulated duration of approximately 29 days (i.e., $2.5 \mathrm{E}+6$ seconds) and assumed a total heat source of approximately $29 \mathrm{~kW}$, which included decay heat $(22.44 \mathrm{KW})$, electrical loads $(1.0 \mathrm{KW})$, and solar heating $(6.0 \mathrm{KW})$.

Therefore, for scoping calculations and to provide some additional conservatism, the maximum (i.e., vault) airspace temperatures obtained from the previous LOFF analysis were input as boundary conditions for the modified storage cubicle and the axi-symmetric 3013 thermal models. Boundary temperature conditions based on a whole vault analysis are necessary, since the ambient temperatures within the vault will be changing with time. This will affect the energy removed by the convective heat transfer coefficients and thermal radiation.

Figure 14 presents the ambient air vault temperature versus time that was used for the LOFF analyses. The ambient air temperatures within the vault range from an initial condition of $80^{\circ} \mathrm{F}$ to the final end-state condition of $118.2^{\circ} \mathrm{F}$.

Figure 27 presents the maximum concrete temperature versus time for the simulated LOFF analysis obtained from the full height $(\mathrm{XY})$ storage cubicle model. The LOFF analysis was terminated after a simulated transient time of 2 days ( 48 hours) due to peak concrete 
temperatures approaching $400{ }^{\circ} \mathrm{F}$. The resulting concrete temperatures range from an initial peak temperature of approximately $141^{\circ} \mathrm{F}$ to a peak value of $394.2^{\circ} \mathrm{F}$ after approximately two days. The peak concrete temperatures exceed $200^{\circ} \mathrm{F}$ after approximately 8.2 hours.

Figure 28 presents the peak concrete temperatures for both the front and rear structures versus time for the simulated LOFF analysis. These values were obtained from the axisymmetric (RZ) front-to-back 3013 canister and storage cubicle thermal model. The concrete temperatures range from an initial peak temperature of approximately $141^{\circ} \mathrm{F}$ to a peak value of $446.1{ }^{\circ} \mathrm{F}$ after 15 days. The peak concrete temperature for the front structure will exceed $200^{\circ} \mathrm{F}$ after approximately 11.1 hours. The peak concrete temperature for the rear structure will exceed 200 ${ }^{\circ} \mathrm{F}$ after approximately 21.1 hours. 
HNF-3830, Rev, 0

\section{Table 3.}

Comparison of Reference Conditions for Analysis.

\begin{tabular}{|l|r|r|r|}
\cline { 2 - 4 } \multicolumn{1}{c|}{} & \multicolumn{3}{c|}{ CASE } \\
\hline \multirow{2}{c}{\multicolumn{1}{c|}{}} & 1 & 2 & 3 \\
\hline 3013 Canister Power (Watts) & 30 & 30 & 15 \\
\hline Total Cubicle Power (Watts) & 660 & 660 & 330 \\
\hline Total Vault Volumetric Flow Rate (cfm) & 3000 & 2500 & 1500 \\
\hline Cubicle Volumetric Flow Rate (cfm) & 44.12 & 36.76 & 22.06 \\
\hline Average Velocity ${ }^{*}(\mathrm{ft} / \mathrm{s})$ & 0.5586 & 0.4654 & 0.2793 \\
\hline Reynold's Number & 1719 & 1324 & 794 \\
\hline Inlet Temperature $\left({ }^{\circ} \mathrm{F}\right)$ & 59.0 & 79.0 & 80.3 \\
\hline Temperature Rise $\left({ }^{\circ} \mathrm{F}\right)$ & 48.2 & 28.9 & 48.2 \\
\hline Outlet Temperature $\left({ }^{\circ} \mathrm{F}\right)$ & 107.2 & 107.9 & 128.5 \\
\hline
\end{tabular}

* Minimum flow area in cubicle

** $D_{h}=0.48 \mathrm{ft}(4 A / W P)$ 
HNF-3830, Rev. 0

Table 4.

Comparison of Steady-State Results from the Full Height Storage

Cubicle at Reference Conditions.

\begin{tabular}{|c|c|c|c|c|c|c|}
\hline & & & & \multicolumn{3}{|c|}{ Temperature, ${ }^{0} \mathrm{~F}\left({ }^{\circ} \mathrm{K}\right)$} \\
\hline Case & $\begin{array}{l}\text { Total Vault } \\
\text { Flowrate } \\
\text { (cfm) }\end{array}$ & $\begin{array}{c}3013 \\
\text { Canister/Storage } \\
\text { Cubicle Power } \\
\text { (watts) }\end{array}$ & $\begin{array}{l}\text { Relative } \\
\text { Cross Flow } \\
\text { Velocity }\end{array}$ & Inlet & Peak Concrete & $\begin{array}{l}\text { Peak Outer } \\
\text { Canister }\end{array}$ \\
\hline 1 & 3000 & $30 / 660$ & $1 X$ & $59.0(288.2)$ & $120.5(322.3)$ & $192.5(362.3)$ \\
\hline 2 & 2500 & $15 / 330$ & $1 X$ & $79.0(299.3)$ & $108.4(315.6)$ & $147.1(337.1)$ \\
\hline $3 A$ & 1500 & $15 / 330$ & $1 X$ & $80.3(300.0)$ & $144.4(335.6)$ & $178.4(354.5)$ \\
\hline $3 B$ & 1500 & $15 / 330$ & $9 x$ & $80.3(300.0)$ & $148.3(337.8)$ & $182.8(356.9)$ \\
\hline
\end{tabular}


HNF-3830, Rev, 0

Table 5.

Comparison of Steady-State Results Versus Axial Position Within a Storage Cubicle at Reference Conditions.

\begin{tabular}{|c|c|c|c|c|c|c|c|}
\hline \multirow[b]{2}{*}{ Case } & \multirow{2}{*}{$\begin{array}{c}\text { Vault } \\
\text { Flowrate } \\
\text { (cfm) }\end{array}$} & \multirow{2}{*}{$\begin{array}{c}3013 \\
\text { Canister/Storage } \\
\text { Cubicle Power } \\
\text { (watts) }\end{array}$} & \multirow{2}{*}{$\begin{array}{c}\text { Inlet } \\
\text { Temperature } \\
{ }^{\circ} \mathrm{F}\left({ }^{\circ} \mathrm{K}\right)\end{array}$} & \multicolumn{2}{|c|}{ Air Gap. in $(\mathrm{cm})$} & \multicolumn{2}{|c|}{$\begin{array}{c}\text { Peak Concrete } \\
\text { Temperatures, }{ }^{\circ} \mathrm{F}\left({ }^{\circ} \mathrm{K}\right)\end{array}$} \\
\hline & & & & Front & Rear & Front & Rear \\
\hline 1 & 3000 & $30 / 660$ & $59.0(288.2)$ & $\begin{array}{ll}1.3125 & (3.3338) \\
0.7188 & (1.8256) \\
0.1250 & (0.3175)\end{array}$ & $\begin{array}{l}0.1250(0.3175) \\
0.7188(1.8256) \\
1.3125(3.3338)\end{array}$ & $\begin{array}{l}119.9(322.0) \\
123.9(324.2) \\
140.5(333.4)\end{array}$ & $\begin{array}{l}115.4(319.5) \\
110.9(317.0) \\
109.9(316.4)\end{array}$ \\
\hline 2 & 2500 & $15 / 330$ & $79.0(299.3)$ & $\begin{array}{l}1.31 .25(3.3338) \\
0.7188(1.8256) \\
0.1250(0.3175)\end{array}$ & $\begin{array}{ll}0.1250 & (0.3175) \\
0.7188 & (1.8256) \\
1.3125 & (3.3338)\end{array}$ & $\begin{array}{l}111.7(317.5) \\
114.0(318.7) \\
123.4(324.0)\end{array}$ & $\begin{array}{l}112.2(317.7) \\
109.9(316.4) \\
109.3(316.1)\end{array}$ \\
\hline $3 A$ & 1500 & $15 / 330$ & $80.3(300.0)$ & $\begin{array}{ll}1.3125 & (3.3338) \\
0.7188 & (1.8256) \\
0.1250 & (0.3175)\end{array}$ & $\begin{array}{l}0.1250(0.3175) \\
0.7188(1.8256) \\
1.3125(3.3338)\end{array}$ & 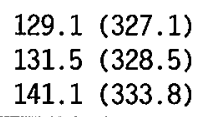 & $\begin{array}{ll}133.1 & (329.3) \\
130.6 & (327.9) \\
130.0 & (327.6)\end{array}$ \\
\hline
\end{tabular}


HNF-3830, Rev. 0

Figure 16.

Steady-State Temperature Contours for a Full Height Storage

Cubicle at Case $3 \mathrm{~A}$ Conditions.

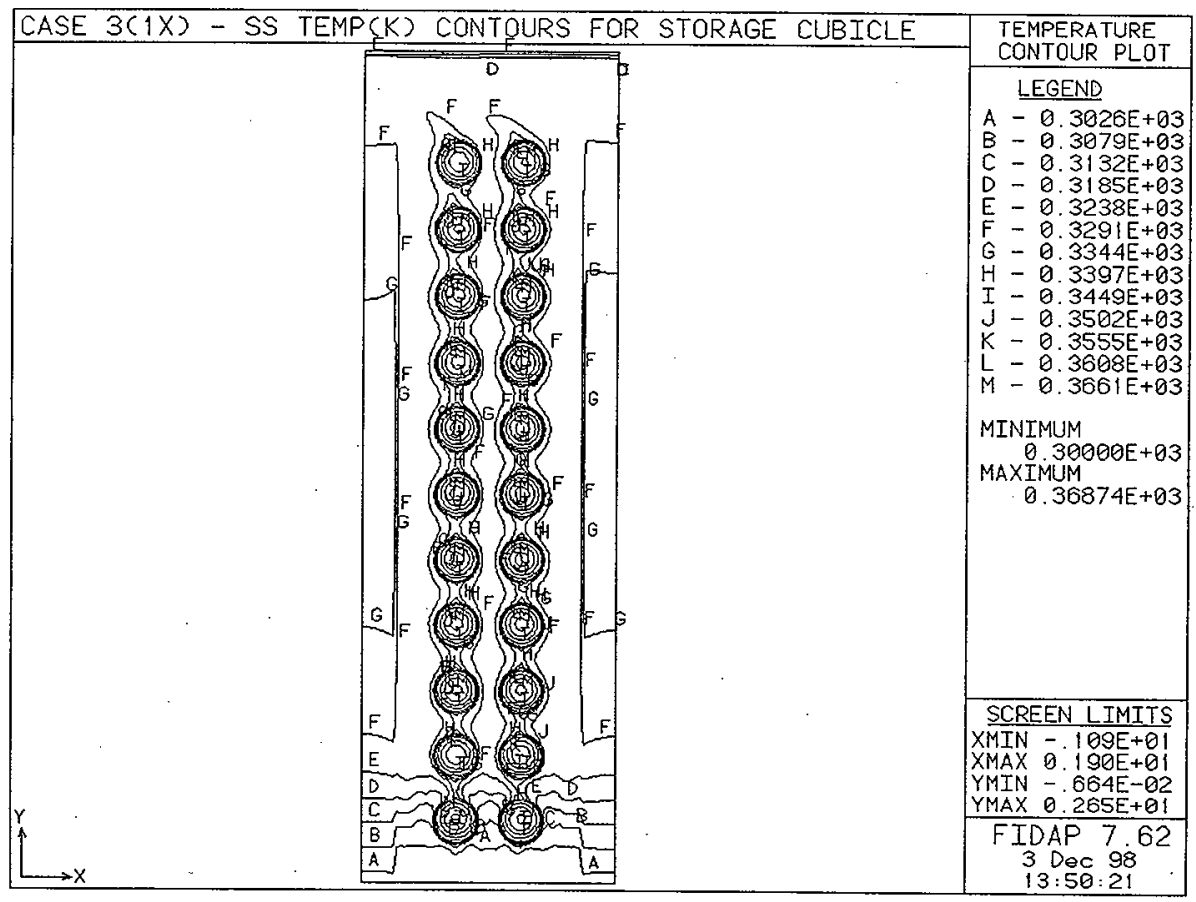


HNF-3830, Rev. 0

Figure 17.

Steady-State Temperature Contours for Upper Third of Storage Cubicle at Case $3 \mathrm{~A}$ Conditions.

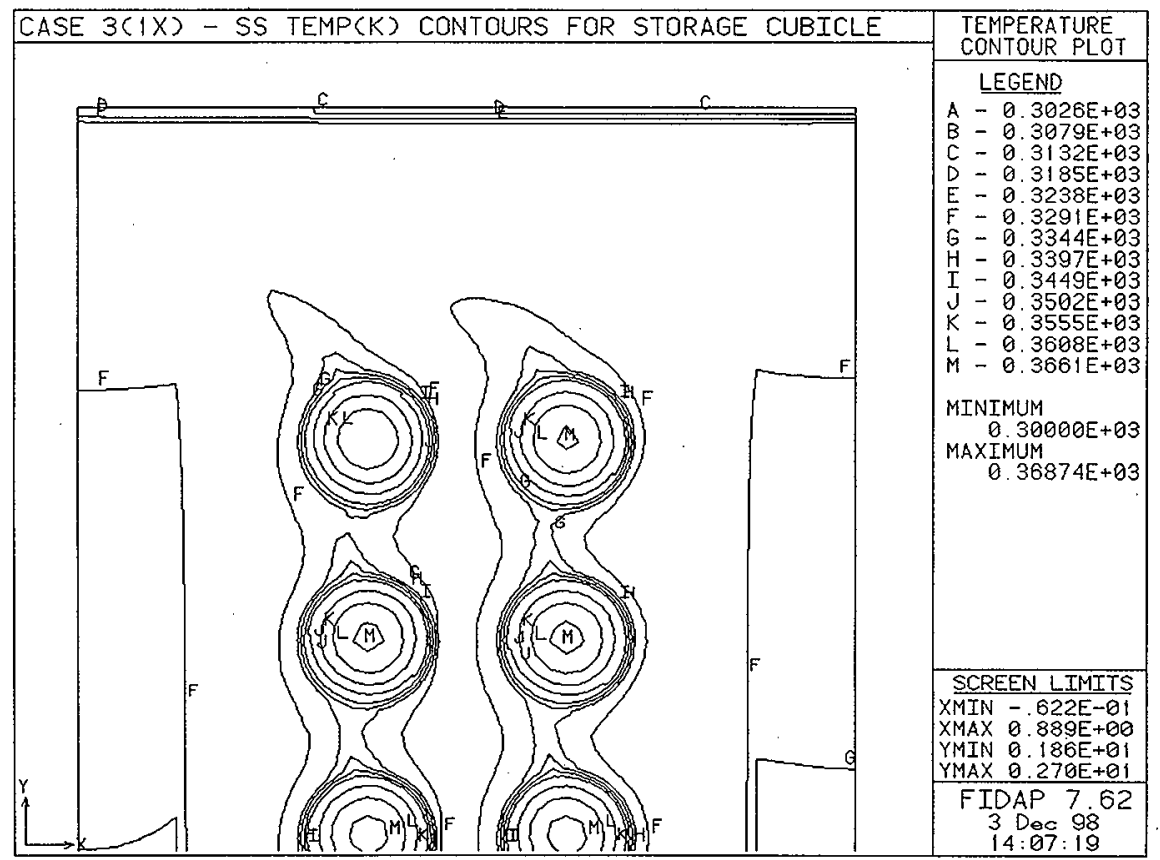


HNF-3830, Rev. 0

Figure 18.

Steady-State Outlet Temperature Distribution Across the Top of the Canister Columns at Case $3 \mathrm{~A}$ Conditions.

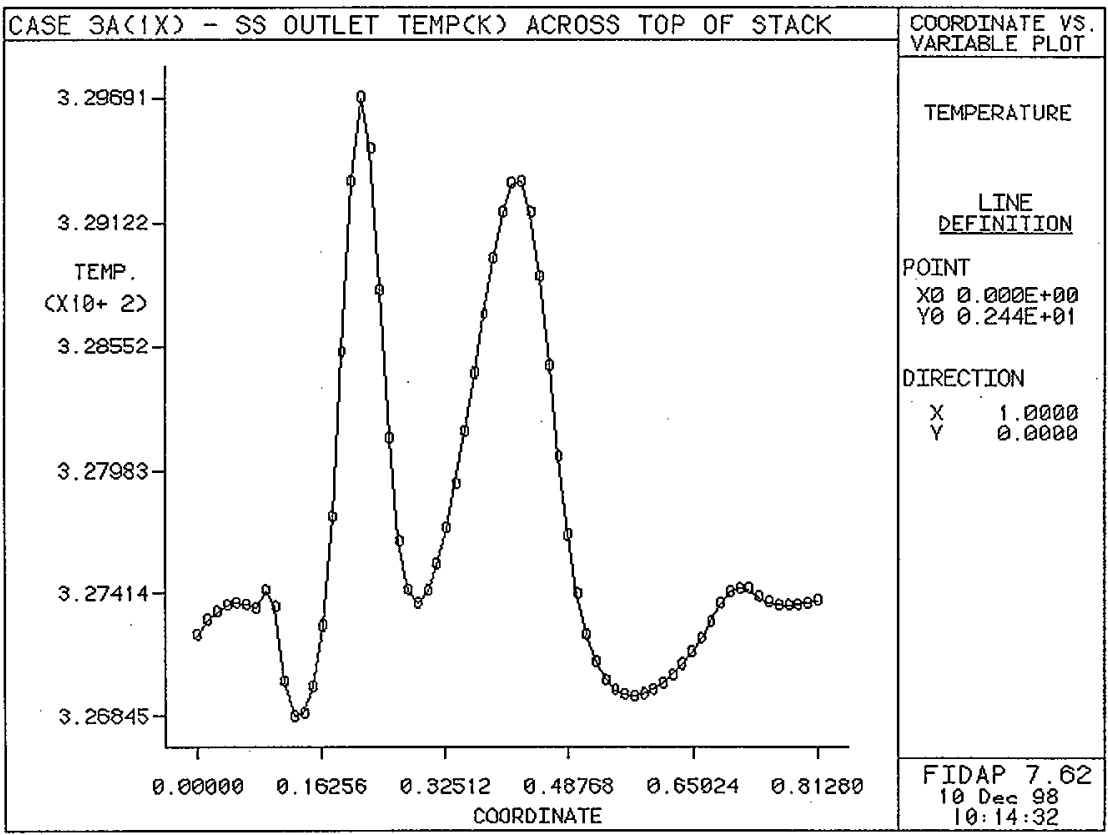


HNF-3830, Rev. 0

Figure 19.

Steady-State Temperature Contours for Left and Right Hand Side Concrete Walls at Case 3A Conditions.

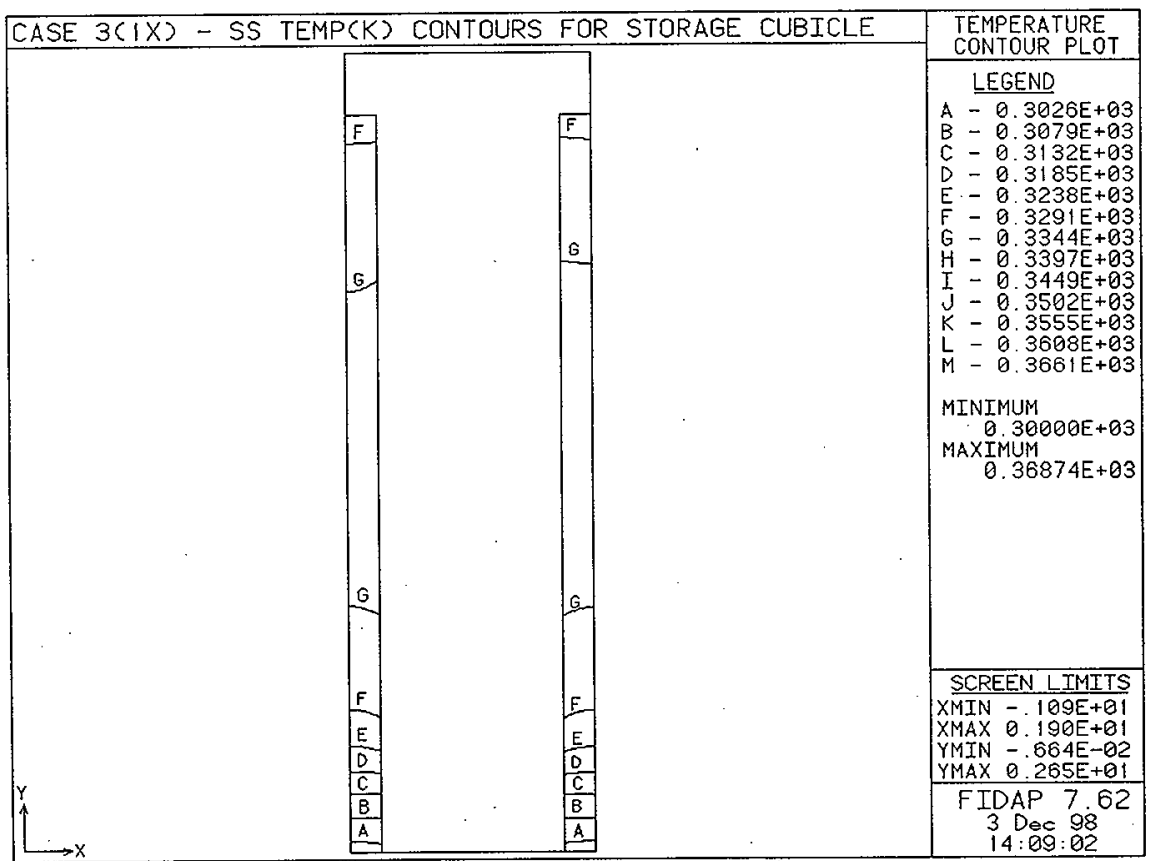


HNF-3830, Rev. 0

Figure 20.

Steady-State Right-Hand Side Concrete Temperature Versus Height Above Basepad at Case 3A Conditions.

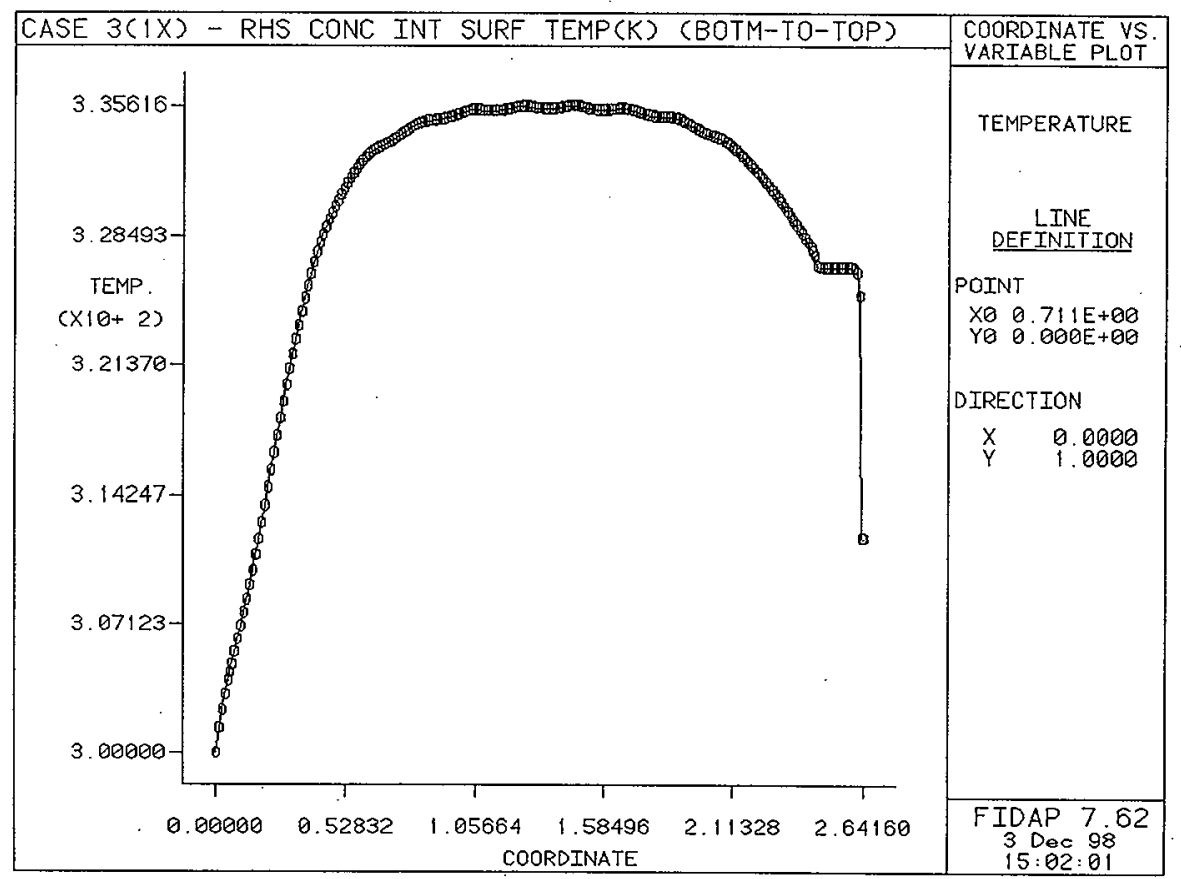


HNF-3830, Rev. 0

Figure 21.

Steady-State Right-Hand Side Concrete Temperature Versus

Height Above Basepad at Case 3B Conditions.

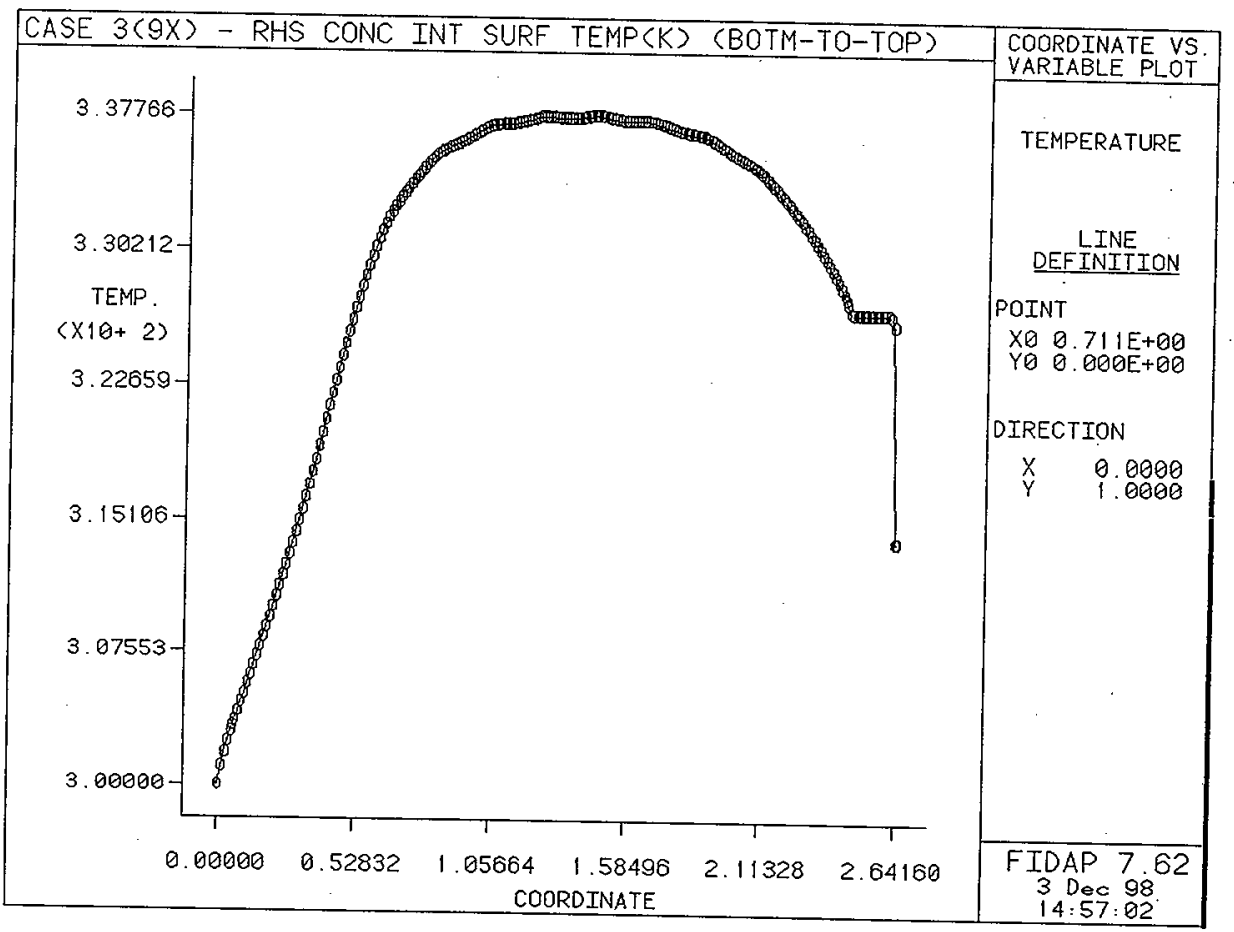


HNF-3830, Rev. 0

Figure 22.

Representative Steady-State Temperature Contours for 3013 Outer Canister Showing Asymmetric Distribution at Case 3A Conditions.

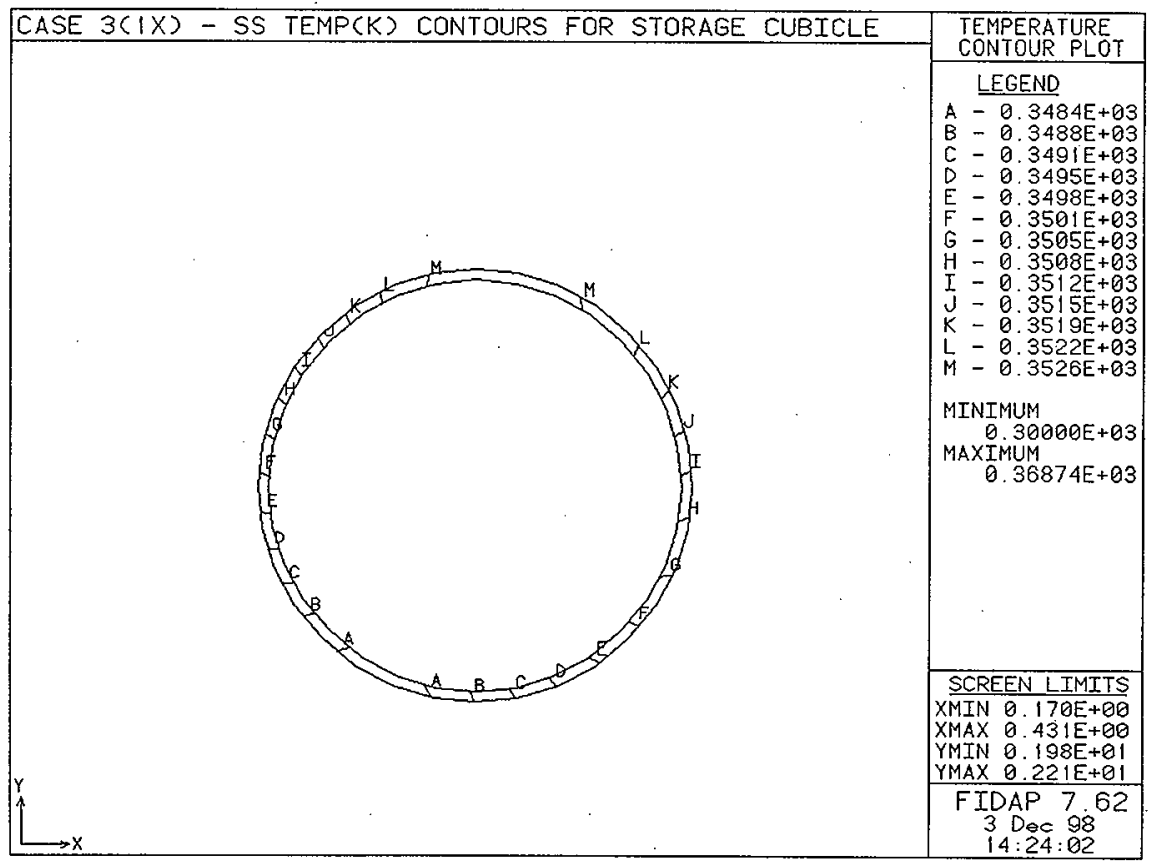


HNF-3830, Rev. 0

Figure 23.

Velocity Vectors for Storage Cubicle at Case 3A Conditions.

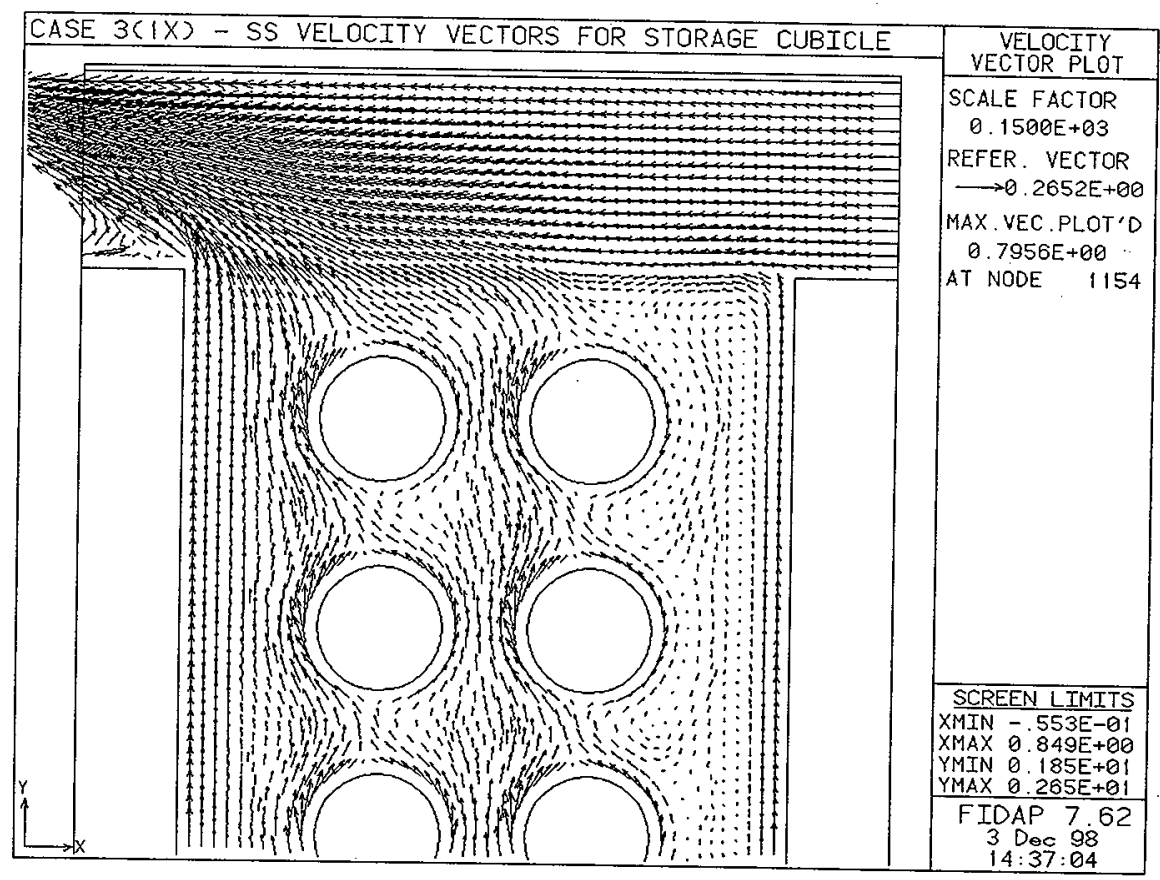


HNF-3830, Rev. 0

Figure 24.

Steady-State Temperature Contours for Axi-Symmetric Thermal Model at Case $3 \mathrm{~A}$ Conditions.

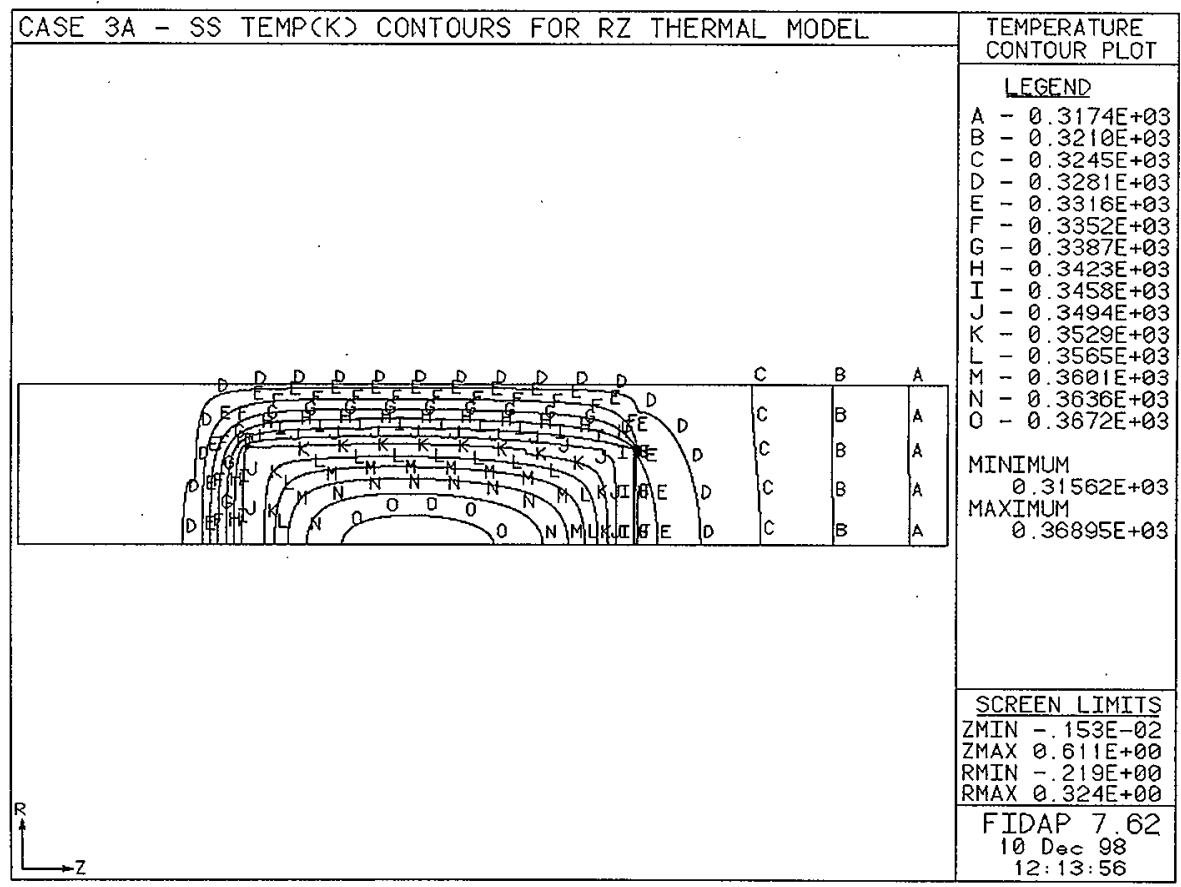


HNF-3830, Rev. 0

Figure 25.

Steady-State Temperature Contours for Front Third of Axi-Symmetric

Thermal Model at Case 3A Conditions.

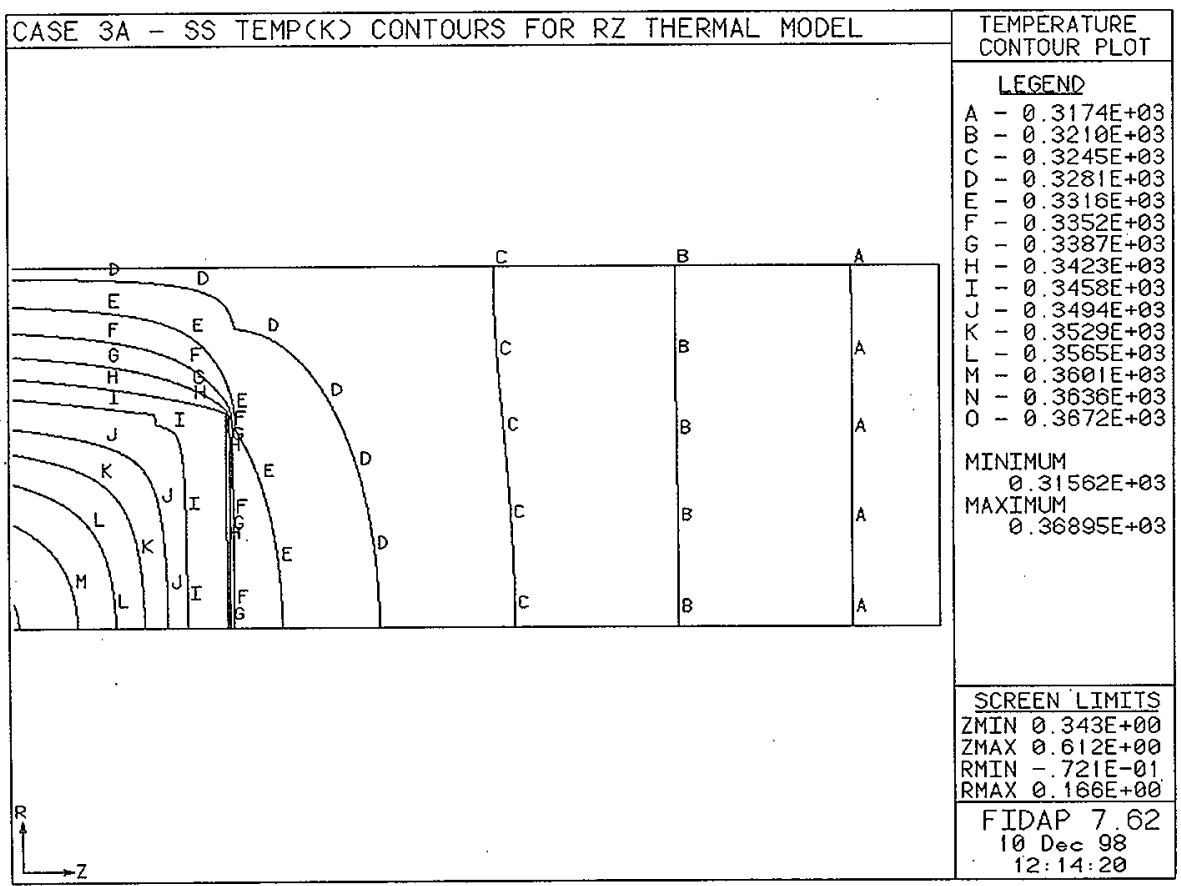


HNF-3830, Rev. 0

Figure 26.

Front Concrete Temperature Versus Distance From Centerline for Minimum Front Gap.

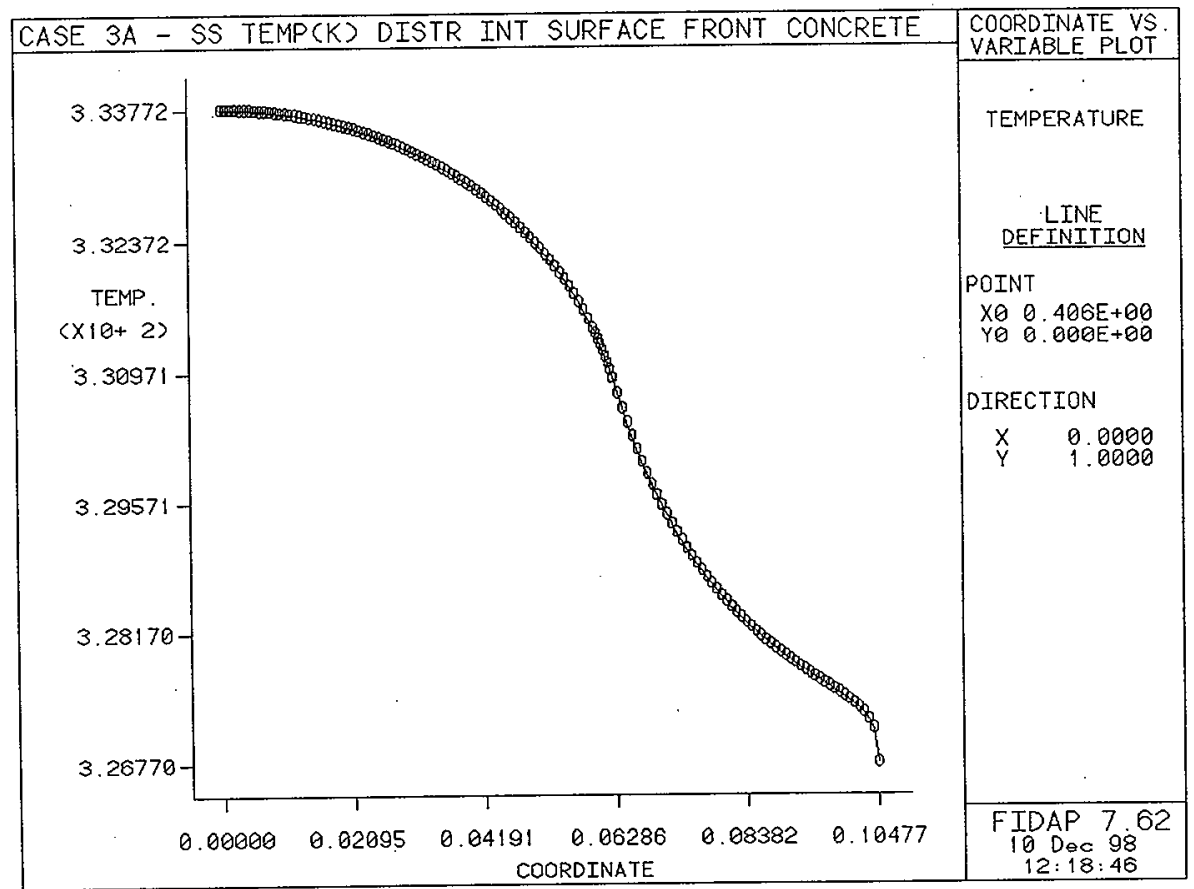


HNF-3830, Rev. 0

Figure 27.

Peak Concrete Temperature Versus Time During LOFF for Full Height Storage Cubicle Model for Case 3A(1X) Initial Conditions.

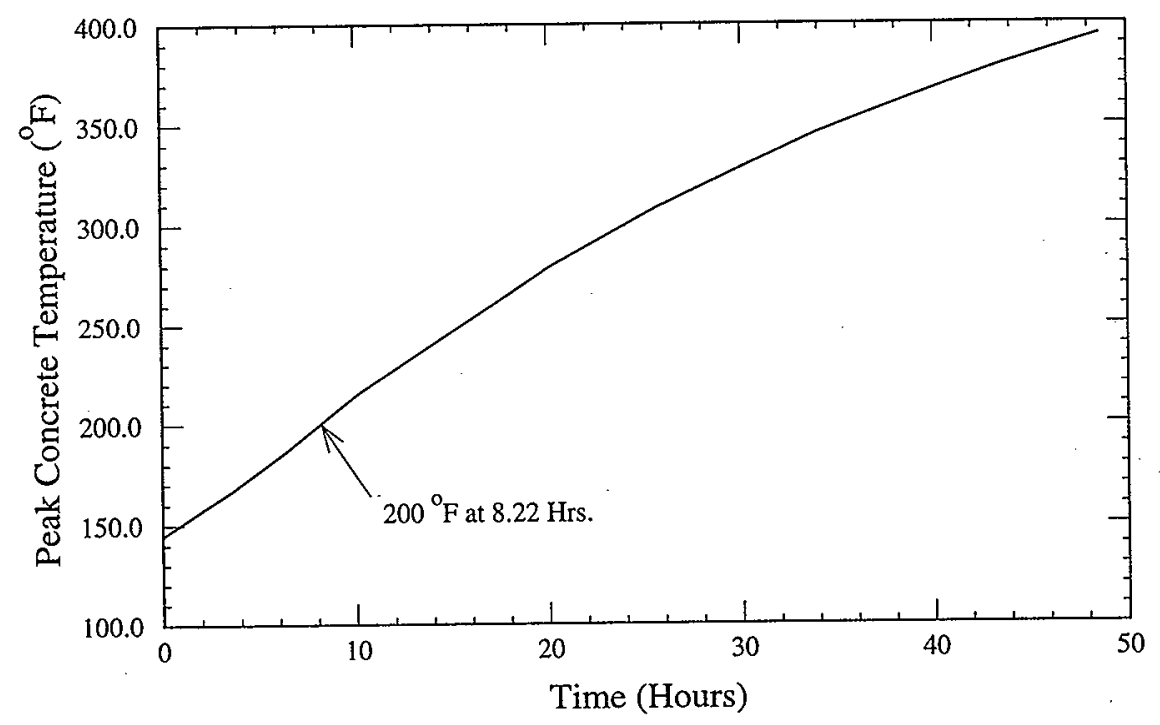




\section{HNF-3830, Rev. 0}

Figure 28.

Peak Concrete Temperature Versus Time During LOFF for Axi-Symmetric Front-To-Rear (RZ) 3013 Canister and Storage Cubicie Model.

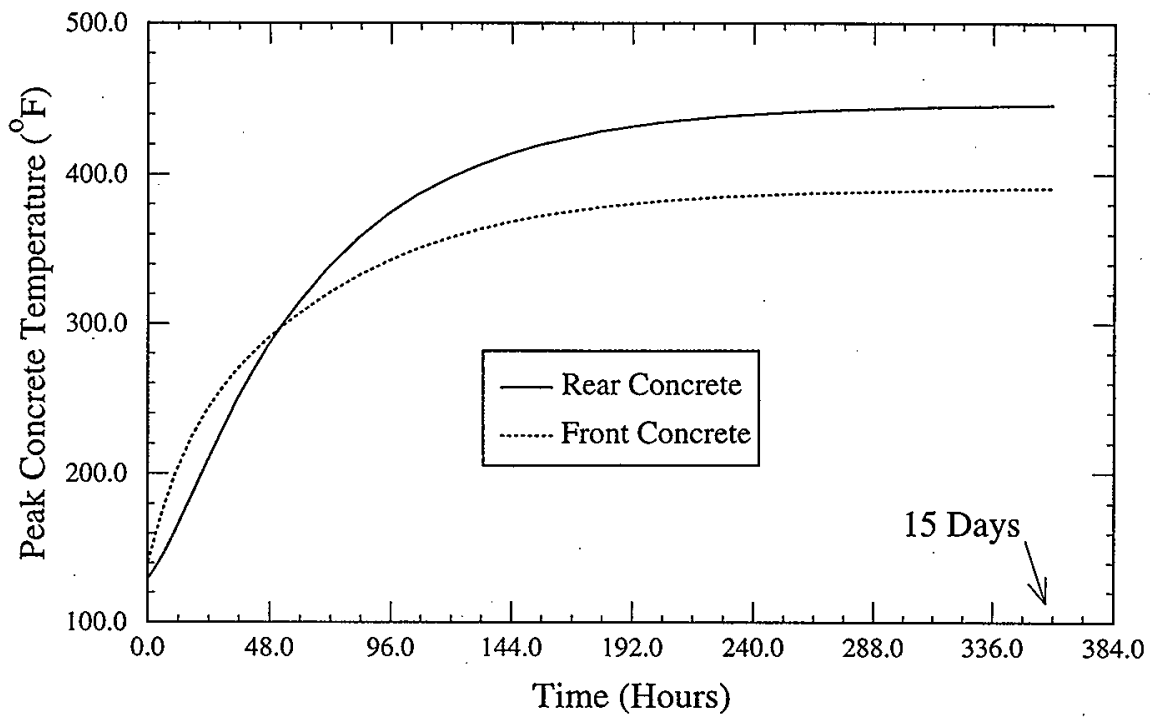


HNF-3830, Rev. 0

Figure 29.

Temperature Contours for Axi-Symmetric Thermal Model During LOFF at 11.08 Hours.

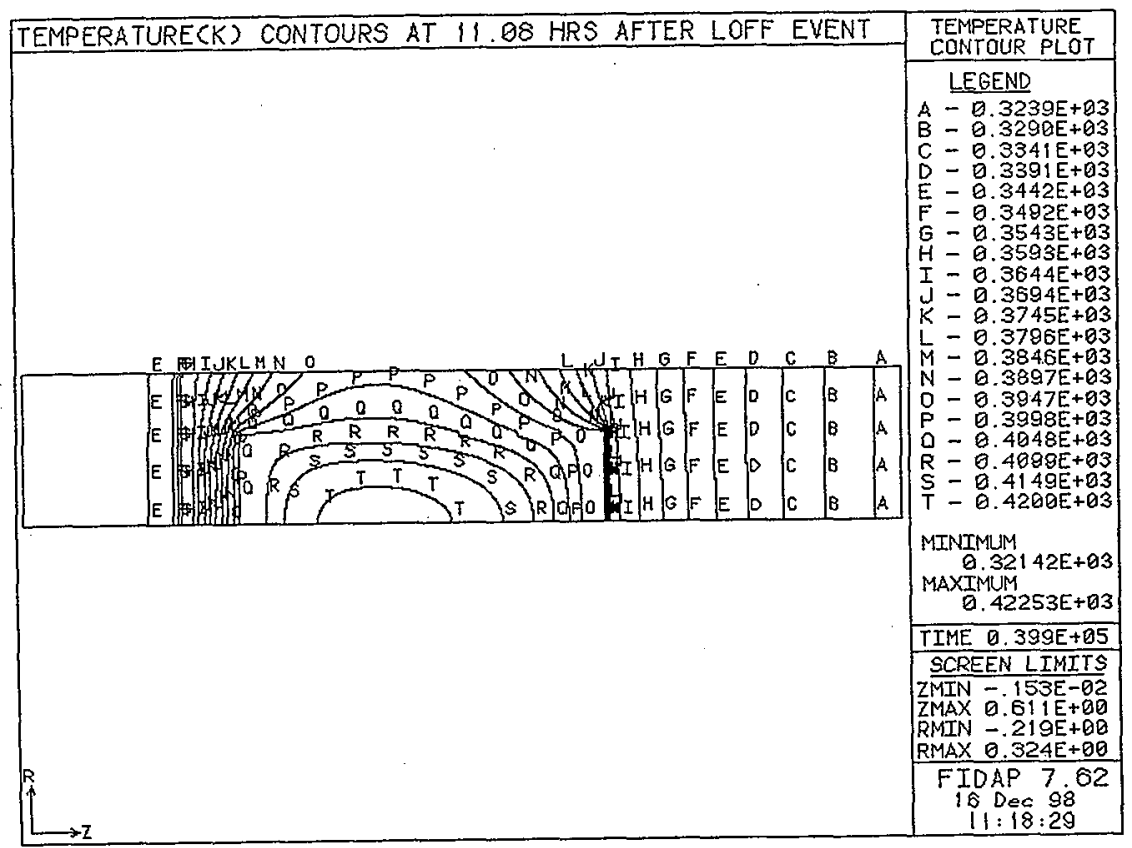


HNF-3830, Rev. 0

Figure 30.

Temperature Contours for Axi-Symmetric Thermal Model During LOFF at 360 Hours.

\begin{tabular}{|c|c|}
\hline \multicolumn{2}{|l|}{ TEMPERATURE (K) CONTOURS AT 360 HRS AFTER LOFF EVENT } \\
\hline 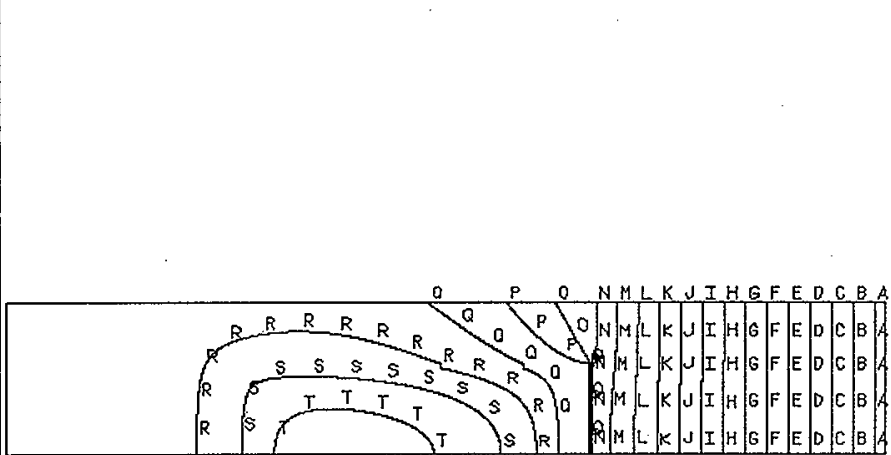 & $\begin{array}{c}\text { LEGEND } \\
A=0.3636 E+03 \\
B=0.3721 E+03 \\
C=0.3897 E+03 \\
D=0.3892 E+03 \\
E=0.3978 E+03 \\
F=0.4064 E+03 \\
G=0.4149 E+03 \\
H=0.4235 E+03 \\
I=0.4320 E+03 \\
J=0.4406 E+03 \\
K=0.4492 E+03 \\
L=0.4577 E+03 \\
M=0.4653 E+03 \\
N=0.4749 E+03 \\
D=0.4834 E+03 \\
P=0.4920 E+03 \\
O=0.5005 E+03 \\
R=0.5091 E+03 \\
S=0.5177 E+03 \\
T=0.5202 E+03\end{array}$ \\
\hline \multirow[b]{4}{*}{$\underset{R}{\longrightarrow}$} & $\begin{array}{l}\text { MINTMUM } \\
\qquad .35927 E+03 \\
\text { MAXIMUM } \\
0.53050 E+03\end{array}$ \\
\hline & TIME Q.129E+07 \\
\hline & $\begin{array}{l}\text { SCREEN LIMITS } \\
\text { ZMIN }-.153 \mathrm{E}-02 \\
\text { ZMAX } 0.611 \mathrm{E}+00 \\
\text { RMIN }-.219 \mathrm{E}+00 \\
\text { RMAX } 0.324 \mathrm{E}+00\end{array}$ \\
\hline & $\begin{array}{c}\text { FID AP } 7.62 \\
16 \text { Dec } 98 \\
11: 20: 47\end{array}$ \\
\hline
\end{tabular}


HNF-3830, Rev. 0

\subsection{CONCLUSIONS AND RECOMMENDATIONS}

Four separate models were developed for the thermal assessment of the modified concrete plutonium storage cubicles with horizontal 3013 canisters. This was necessary to handle the change in dimensional scales ranging from the full height concrete storage cubicles to the relatively thin walls and small separation distances among the three containers that comprise a 3013 canister. The thermal-hydraulic models increase in detail and complexity as the dimensional scale decreases.

The goal of these analyses was to determine the peak concrete and component temperatures during nominal steady-state operations for various ventilation flow rates and inlet temperatures, as well as the peak transient temperatures associated with a postulated loss-of-forced ventilation flow (LOFF) event. The analyses focused on a single concrete storage cubicle with maximum decay heat. These analyses are expected to provide general guidance on the feasibility of using the existing, but modified concrete storage cubicles with horizontal placement of 3013 canisters.

NOTE:The subject thermal analyses are considered conceptual and must be reviewed for applicability prior to implementing horizontal storage of 3013 canisters. Any revisions to the current design concept, technical bases, and assumptions, as documented within this report, may require additional thermal analyses to demonstrate compliance with peak concrete temperatures.

The following conclusions are made:

1. The nominal peak concrete temperatures are expected to be less than $150^{\circ} \mathrm{F}$ during steady-state operations. Peak concrete temperatures range between $144^{\circ} \mathrm{F}$ and $148^{\circ} \mathrm{F}$ for the range of Case 3 conditions shown in Table 3 . This is very close to maximum value of $150^{\circ} \mathrm{F}$, as recommended by the American Concrete Institute (ACD) for normal operations or any other long term period. However, the results are based on a series of conservative assumptions that are not expected to simultaneously occur within any one cubicle.

2. The peak concrete temperatures during a Loss-Of-Forced Flow (LOFF) event will exceed $200^{\circ} \mathrm{F}$ within approximately 8 hours.

3. Uncertainties in the cubicle flow rate, inlet temperature, and canister heat loads could result in nominal steady-state peak concrete temperatures greater than $150^{\circ} \mathrm{F}$. These uncertainties can result from the following;

- Bypass or leakage air flow through the various edge, lap, and upper gaps surrounding the concrete doors

- Inlet temperature variations due to seasonal or building heat loads 
- Canister heat loads greater than 15 watts due to the buildup of Americium-241 and other high order decay isotopes.

The following recommendations are offered:

1. Center the 3013 canisters front-to-rear with approximately 0.75 inch gaps between the rear liner plate and front concrete door. Small tabs projecting from the supporting straps are recommended as stops. It is recommended that the 3013 canister not be allowed to touch either the front door or the rear liner plate as this would provide a conduction path to remove the energy from the canister and would create a hot spot.

2. Seal all door edge, lap, and upper gaps with high temperature radiation resistant metal tape. (Do not seal the lower 1.5 by 24 inch gap under the door.) This will prevent flow from bypassing the canister columns and increasing the concrete temperatures.

3. Remove as much as possible of the old vertical support racks and canister shelves. The thermal-hydraulic models assumed that there was little or no flow resistance due to the remaining structure.

4. Vault inlet ventilation air temperatures must not exceed $82^{\circ} \mathrm{F}$. This is based on the small margins to a peak concrete temperature of $150^{\circ} \mathrm{F}$ from the Case $3 \mathrm{~A}(9 \mathrm{X})$ analysis summarized in Table 4.

5. The maximum initial heat load of the 3013 canisters must include sufficient margin to 15 watts to accommodate the buildup of high decay heat isotopes such as Americium-241.

6. Emergency response procedures must reflect a requirement to restore nominal vault flow within eight hours.

7. Although not explicitly required for the analyses documented within this report, the thermal conductivity data for plutonium oxide is extremely sparse. Current measurements have large uncertainties for oxide powder densities less than $6.0 \mathrm{gm} / \mathrm{cm}^{3}$. Additional thermal conductivity data is required for $\mathrm{PuO}_{2}$ versus temperature and powder densities less than $6.0 \mathrm{gm} / \mathrm{cm}^{3}$ for various fill gases (i.e., air, helium, and argon). It is recommended that a laboratory program be established to provide measured values of thermal conductivity for plutonium oxide powder. It is anticipated that such a program will help refine the thermal assessments for the 3013 canisters during future conversion, long term storage, or transportation activities. 
HNF-3830, Rev. 0

\subsection{REFERENCES}

Heard, F. J., 1994, "FIDAP Version 7.06 - Validation and Verification", WHC-SD-WM-ER302, Rev. 1, Westinghouse Hanford Company, Richland, Washington.

Holman, J. P., 1990, "Heat Transfer", Seventh Edition, McGraw-Hill, Inc., New York, New York.

Internal letter memo, Heard, F. J. to G. A. Johnston, C. T. O'Neil, and R.W.Szempruch, "Results of Thermal-Hydraulic Assessment for the 2736Z Building Vault \#2 With the Proposed in-Floor Storage Vault", 74350-96-FJH-025, Rev. 0, Lockheed Martin Hanford Corporation, dated November 12, 1996.

Internal letter memo, Heard, F. J. To G. A. Johnston, et. al., "Results of the ThermalHydraulic Assessment for the Hanford Convenience Can Storage Containers and Storage Racks," 8C453-97-FJH-001, Numatec Hanford Corporation, date June 6, 1997.

Irwin, J. J., 1993, "Thermal Analysis Methods for Safety Analysis Report for Packing", WHC-SD-TP-RPT-005, Rev. 0, Westinghouse Hanford Company, Richland, Washington.

Jerrell, J. W. and P. Lam, 1994, "Thermal Analysis of Storage Cans Containing Special Nuclear Materials", WSRC-TR-94-0418, Savannah River Technology Center, Aiken, South Carolina, Westinghouse Savannah River Company.

Katz, Seaborg, and Moore, "Chemistry of Actinide Elements", Volume 1, 1990.

Siegel, R. and J. R. Howell, "Thermal Radiation Heat Transfer", Third Edition, Hemisphere Publishing Corporation, Philadelphia, Pa., 1992.

Short, S. M., and M. M. Beary, 1995, "SNF Project Technical Databook", WHC-SDSNF-Tl-015, Rev. 0, Westinghouse Hanford Company, Richland, Washington. 


\author{
HNF -3830 , Rev. 0
}

\title{
APPENDIX A
}

User Subroutine Listings for Evaluating Heat Transfer Coefficients for Variable Ambient Temperatures.

\author{
USRCNV.SUB - User subroutine to calculate heat transfer \\ coefficients for variable ambient temperature. \\ USRINI.SUB - User input subroutine to read ambient temperature \\ versus time from a separate input file. \\ USRREF.SUB - User subroutine to determine the ambient \\ temperature given transient time.
}


HNF-3830, Rev. 0

\begin{abstract}
SUBROUTINE USRCNV (NELT, NE, NG, HC, VARI , NDFCD, LDOFU, SHP, XYZL, 1

PROP, TIME, NPTS, ndp, MNDP, IERR)
\end{abstract}

C

C

C

C NELT $=$ GLOBAL ELEMENT NUMBER

$C \quad \mathrm{NE} \quad=$ LOCAL ELEMENT NUMBER

$C \quad N G \quad=$ GROUP NUMBER

C HC = CONVECTION COEFFICIENT

C VARI $=$ SOLUTION VARIABLE ARRAY AT THE INTEGRATION POINTS

C LDOFU = pointer array for accessing vari and dvari information

C $\quad X Y Z L=X, Y, Z$ COORDINATES

C PROP $=$ USER DEFINED PARAMETERS

C MNDP $=$ FIRST DIMENSION OF SHAPE FUNCTION MATRICES

C TIME $=$ TIME

C NPTS $=$ NUMBER OF POINTS

C

INCLUDE 'IMPLCT.COM'

INCLUDE 'PARUSR.COM'

COMMON /AMBT/ TAMBVLT $(340,2), \operatorname{TVNORM}(340,2)$

COMMON /REFT/ REFVLT,DELTA, NPRINT, MULT

INTEGER ICOUNT

REAL TEMP, RHO , CP, VIS, KOND, PRNBER, JTEMP, KTEMP

DIMENSION TEMP (34), RHO(34), CP(34), VIS(34), KOND(34)

DIMENSION PRNBER(34)

DIMENSION HC(NPTS), SHP(MNDP, NPTS), XYZL(NPTS, NDFCD)

DIMENSION PROP(*), VARI (NPTS, *), LDOFU(*)

$\mathrm{C}=0.0$

$X M=0.0$

GRAVITY $=9.80665$

C MATERIAL PROPERTIES FOR AIR - ALL PROPS RANGE FROM 100K TO 2500K

C TEMPERATURE DATA IN DEGREES KELVIN (K)

DATA TEMP/ $100.0,150.0,200.0,250.0,300.0,350.0,400.0,450.0,500.0$,

$+\quad 550.0,600.0,650.0,700.0,750.0,800.0,850.0,900.0,950.0$,

$+\quad 1000.0,1100.0,1200.0,1300.0,1400.0,1500.0,1600.0,1700.0$,

$+\quad 1800.0,1900.0,2000.0,2100.0,2200.0,2300.0,2400.0,2500.01$

C DENSITY(RHO) FOR AIR IN KILOGRAMS PER CUBIC METER (KG/M3)

DATA RHO/3.6010, 2.3675, 1.7684,1.4128, 1.1774, 0.9980, 0.8826, 0.7833,

$+\quad 0.7048,0.6423,0.5879,0.5430,0.5030,0.4709,0.4405,0.4149$,

$+\quad 0.3925,0.3716,0.3524,0.3204,0.2947,0.2707,0.2515,0.2355$,

$+\quad 0.2211,0.2082,0.1970,0.1858,0.1762,0.1682,0.1602,0.1538$,

$+\quad 0.1458,0.1394 /$ 
C SPECIFIC HEAT(CP) FOR AIR IN JOULES PER KILOGRAMS PER DEGREE K (J/KG-K)

DATA CP/1026.6,1009.9, 1006.1,1005.3,1005.7,1009.0,1014.0,1020.7, $+\quad 1029.5,1039.2,1055.1,1063.5,1075.2,1085.6,1097.8,1109.5$,

$+\quad 1121.2,1132.1,1141.7,1160.0,1179.0,1197.0,1214.0,1230.0$,

$+\quad 1248.0,1267.0,1287.0,1309.0,1338.0,1372.0,1419.0,1482.0$,

$+\quad 1574.0,1688.0 /$

C VISCOSITY(VIS) FOR AIR IN KILOGRAMS PER METER PER SECOND (KG/M-S) $\times 1.0 E+5$

DATA VIS $/ 0.6924,1.0283,1.3289,1.5990,1.8462,2.0750,2.2860,2.4840$,

$+\quad 2.6710,2.8480,3.0180,3.1770,3.3320,3.4810,3.6250,3.7650$,

$+\quad 3.8990,4.0230,4.1520,4.4400,4.6900,4.9300,5.1700,5.4000$,

$+\quad 5.6300,5.8500,6.0700,6.2900,6.5000,6.7200,6.9300,7.1400$,

$+\quad 7.3500,7.5700 /$

C CONDUCTIVITY(KOND) FOR AIR IN JOULES PER SECOND PER METER PER DEGREE $K$ $(J / S-M-K)$

DATA KOND/0.0009246, 0.013735, 0.01809,0.02227, 0.02624,0.03003,

$+\quad 0.03365,0.03707,0.04038,0.04360,0.04659,0.04953$,

$+\quad 0.05230,0.05509,0.05779,0.06028,0.06279,0.06525$,

$+\quad 0.06752,0.07320,0.07820,0.08370,0.08910,0.09460$,

$+\quad 0.10000,0.10500,0.11100,0.11700,0.12400,0.13100$,

$+\quad 0.13900,0.14900,0.16100,0.17500 /$

C PRANTL(PRNBER) NUMBER FOR AIR IS DIMENSIONALESS

DATA PRNBER/0.770,0.753,0.739,0.722, 0.708,0.697, 0.689,0.683,0.680,

$+\quad 0.680,0.680,0.682,0.684,0.686,0.689,0.692,0.696,0.699$,

$+\quad 0.702,0.704,0.707,0.705,0.705,0.705,0.705,0.705,0.704$,

$+\quad 0.704,0.702,0.700,0.707,0.710,0.718,0.730 /$

IF (MULT.EQ.0) THEN

DO $50 \quad I=1,34$

$\operatorname{VIS}(I)=V I S(I) * 1.0 \mathrm{E}-5$

50 CONTINUE

ENDIF

MULT $=1$

IF (NPRINT.EQ.1) THEN

GOTO 199

ELSE

$\mathrm{C}$

C INSERT OPEN STATEMENT

$C$ INSERT ANY PRINT STATEMENTS

C INSERT CLOSE

C

NPRINT $=1$

ENDIF

199 CONTINUE

$\mathrm{I}=0$ 
HNF-3830, Rev. 0

ICOUNT $=0$

D0 75 II $=1$, NPTS

$\mathrm{HC}(\mathrm{II})=0.0$

75 CONTINUE

C START OF REALY BIG BIG BIG LOOP

DO $100 \mathrm{I}=1$, NPTS

ICOUNT $=I$

$\mathrm{J}=0$

$J J=0$

TWALL $=0.0$

CHARL $=0.0$

$\mathrm{DT}=0.0$

RATIO $=0.0$

$\mathrm{GR}=0.0$

$\mathrm{RA}=0.0$

TFILM $=0.0$

TRHO $=0.0$

$\mathrm{TCP}=0.0$

TVIS $=0.0$

TKOND $=0.0$

TPR $=0.0$

TBETA $=0.0$

TAMB $=0.0$

TWALL=VARI $(I$, LDOFU(KDT) $)$

TAMB=REFVLT

DT=ABS ( TWALL - TAMB)

TFILM $=($ TWALL+TAMB $) / 2.0$

C DETERMINE AIR PROPERTIES FOR EACH POINT AT CORRESPONDING TFILM

DO $200 \mathrm{JJ}=2,34$

IF ((TFILM.LT.TEMP(JJ)).AND. (TFILM.GE.TEMP(JJ-1))) THEN

$\mathrm{J}=\mathrm{JJ}$

GOTO 300

ELSE

GOTO 200

ENDIF

200 CONTINUE

300 CONTINUE

$J T E M P=\operatorname{TEMP}(J-1)$

$K T E M P=T E M P(J)$

RATIO $=($ TFILM $-J T E M P) /($ KTEMP $-J T E M P)$

$T R H O=R H O(J-1)+(R H O(J)-R H O(J-1)) * R A T I O$

$T C P=C P(J-1)+(C P(J)-C P(J-1)) * R A T I O$

TVIS $=V I S(J-1)+(V I S(J)-V I S(J-1)) * R A T I O$ 
TKOND $=K O N D(J-1)+(K O N D(J) \cdot K O N D(J-1)) * R A T I O$

TPR=PRNBER(J-1)+(PRNBER(J) $-\operatorname{PRNBER}(\mathrm{J}-1)) *$ RATIO

TBETA $=1.0 /$ TFILM

C GET CORRECT CHARACTERISTIC LENGTH FOR KNOWN CONV GRPS FROM USER INPUT CHARL=PROP (1)

C CALCULATE GRASHOF AND RAYLEIGH NUMBERS

$G R=(T R H O * * 2) * G R A V I T Y * T B E T A * D T * C H A R L * * 3 / T V I S * * 2$

$R A=G R * T P R$

C USER PROGRAMMED HT CORRELATIONS FOR UPPER SURFACES

C OF HEATED PLATES

C SEE TABLE 7.1 (HOLMAN)

C DETERMINE WHICH CONSTANT $C$ AND $m$ TO USE FOR HC CORRELATIONS

IF ((GR.GE. 2.0E+4).AND. (GR.LT.8.0E+6)) THEN

$C=0.54$

$\mathrm{XM}=0.25$

HC $($ ICOUNT $)=($ TKOND $/$ CHARL $) * C * R A * * X M$

GOTO 100

ENDIF

IF ((GR.GE $.8 \cdot 0 \mathrm{E}+6) \cdot$.AND. (GR.LE $1 \cdot 0 \mathrm{E}+11))$ THEN

$C=0.15$

$X M=0.33333$

$H C($ ICOUNT $)=($ TKOND $/$ CHARL $) * C * R A * * X M$

GOTO 100

ENDIF

C IF THE CALC VALUE OF GR DOES NOT WITHIN THE ABOVE RANGES USE

C THE FOLLOWING CORRLEATION

C SEE HOLMAN EQUATION 7.29

HC $($ ICOUNT $)=($ TKOND $/$ CHARL $) *(0.825+(0.387 * R A * * 0.1667) /((1+(0.492 /$ TPR $)$

$+* * 0.5625) * * 0.2962963)) * * 2$

100 CONTINUE

RETURN

END

SUBROUTINE USRINI (INIVAR)

C

C USER SET FLAGS FOR ENSURING OF THE COMPUTATION

C OF VARI AND DVARI ARRAYS FOR VARIABLES CHOSEN BY THE USER

$C$ INIVAR COMES IN SET TO ZERO, IF THE USER DESIRES A VARIABLE

C TO BE COMPUTED AT THE INTEGRATION POINTS FOR A USER SUBROUTINE

C THEN SETTING INIVAR TO A NONZERO VALUE WILL FORCE COMPUTATION

C THE INDICES ARE $K D U=U$-VELOCITY $\quad K D V=V-V E L O C I T Y$

C

$\mathrm{C}$

$\mathrm{KDW}=W \cdot$ VELOCITY $\quad \mathrm{KDK}=\mathrm{KINETIC}$ ENERGY

KDE $=$ DISSIPATION $\quad$ KDT $=$ TEMPERATURE

C $\quad K D S+I=$ FOR SPECIES I $(I=1$ to 15$)$ 
HNF-3830, Rev. 0

C $\quad$ KDP $=$ PRESSURE

C

INCLUDE 'IMPLCT.COM'

INCLUDE 'PARUSR. COM'

COMMON /AMBT/ TAMBVLT $(340,2), \operatorname{TVNORM}(340,2)$

COMMON /REFT/ REFVLT, DELTA, NPRINT,MULT

DIMENSION INIVAR(*)

NPRINT $=0$

MULT $=0$

REFVLT $=300.00000$

DELTA $=1.84$

D0 $10 \mathrm{~J}=1,2$

DO $20 \mathrm{I}=1,340$

$\operatorname{TAMBVLT}(I, J)=0.0$

$\operatorname{TVNORM}(I, J)=0.0$

20 CONTINUE

10 CONTINUE

C READ IN AMBIENT AIR TEMPERATURES RESULTS FROM LUMPED PARAMETER

C WHOLE BUILDING MODEL FOR LOFF SIMULATION

C TAMB FOR VAULT AIR SURROUNDING CUBICLES

OPEN(28, FILE=' VAULT2AIR. DAT' , FORM=' FORMATTED' , READONLY, +STATUS=' OLO' , ACCESS= 'SEQUENTIAL')

$\operatorname{READ}(28,100)$ (TAMBVLT $(I, 1), \operatorname{TAMBVLT}(\mathrm{I}, 2), \mathrm{I}=1,340$ )

CLOSE(28)

D0 $30 \mathrm{I}=1,340$

TAMBVLT $(I, 2)=$ TAMBVLT $(I, 2)+D E L T A$

30 CONTINUE

D0 $40 \quad \mathrm{~J}=1,340$

$\operatorname{TVNORM}(\mathrm{J}, 1)=\operatorname{TAMBVLT}(\mathrm{J}, 1)$

$\operatorname{TVNORM}(\mathrm{J}, 2)=\operatorname{TAMBVLT}(\mathrm{J}, 2) / \operatorname{REFVLT}$

40 CONTINUE

C OPEN(29, FILE=' TAMBWRITE. OUT ' , FORM=' FORMATTED' , STATUS=' NEW',

C +ACCESS $=$ 'SEQUENTIAL')

C WRITE(29,"(' VAULT TIME(S) VRS TEMP(K) ')")

C WRITE $(29,200)$ (TAMBVLT $(I, 1), \operatorname{TAMBVLT}(I, 2), I=1,340)$

C WRITE $(29,200)$ (TVNORM $(I, 1), \operatorname{TVNORM}(I, 2), I=1,340)$

C WRITE $(29,300)$ REFVLT, DELTA, NPRINT, MULT

C CLOSE (29)

100 FORMAT(1X,F12.5,6X, F12.5)

C 200 FORMAT( $1 X, F 15.5,6 X, F 15.5)$

C 300 FORMAT(1X,F15.5,6X,F15.5,6X, I6, 6X, I6)

RETURN

END 
HNF-3830, Rev. 0

$\begin{array}{ll}\text { SUBROUTINE USRREF } & \text { (NELT, NE, NG, REFENV, VARI, NDFCD, LDOFU, } \\ 1 & \text { XYZL, PROP, TIME, NPTS, IPRP , IERR) }\end{array}$

C

C USER DEFINED REFERENCE ENVIRONMENTAL CONDITION

C FOR BOUNDARY CONDITIONS WITH VARYING ENVIRONMENTS

$\mathrm{C}$

C NELT = GLOBAL ELEMENT NUMBER

C NE $\quad=$ LOCAL ELEMENT NUMBER

C NG $\quad=$ GROUP NUMBER

C REFENV = USER DEFINED ENVIRONMENTAL REFERENCE

$\mathrm{C}$ VARI $=$ SOLUTION VARIABLE ARRAY AT THE INTEGRATION POINTS

C $X Y Z L=X, Y, Z$ COORDINATES

C PROP $=$ VALUE OF ENVIRONMENTAL REFERENCE

$\mathrm{C}$ TIME $=$ TIME

C NPTS $=$ NUMBER OF POINTS

C IPRP $=0$ - TEMPERATURE FOR CONVECTION

c

C

C

C -1 - TEMPERATURE FOR EMISSIVITY (RADIATION)

I - SPECIES I

-2 - PRESSURE

INCLUDE 'IMPLCT.COM'

INCLUDE 'PARUSR.COM'

REAL JTIME, KTIME, JTAMB, KTAMB, REFTEMP

COMMON /AMBT/ TAMBVLT $(340,2), \operatorname{TVNORM}(340,2)$

COMMON /REFT/ REFVLT,DELTA, NPRINT, MULT

DIMENSION REFENV(NPTS), VARI (NPTS, *), XYZL (NPTS, NDFCD)

DIMENSION LDOFU(*)

$\mathrm{ZRO}=0 . \mathrm{DO}$

T=TIME

JTIME $=0.0$

KTIME $=0.0$

JTAMB $=0.0$

KTAMB $=0.0$

REFTEMP $=0.0$

DO $1 \mathrm{I}=1$, NPTS

$\operatorname{REFENV}(\mathrm{I})=0.0$

1 CONTINUE

IF ( (IPRP.EQ. - 1).OR. (IPRP.EQ.0) ) THEN

GOTO 50

ELSE

GOTO 700

ENDIF

50 CONTINUE 


$$
\text { HNF-3830, Rev. } 0
$$

C FIND AND BRACKET TEMPERATURES FROM LOFF WHOLE BUILDING SIMULATION

C RESULTS AS STORED IN COMMON BLOCK ENTRY TAMBVLT FROM USRINI

DO $100 \quad I=2,340$

IF ((T.LT.TAMBVLT(I,1)) .AND. (T.GE.TAMBVLT $(I-1,1)))$ THEN

JTIME=TAMBVLT $(\mathrm{I}-1,1)$

KTIME $=$ TAMBVLT $(I, 1)$

JTAMB=TAMBVLT $(I-1,2)$

KTAMB=TAMBVLT $(I, 2)$

GOTO 500

ELSE

GOTO 100

ENDIF

100 CONTINUE

500 CONTINUE

REFTEMP $=$ JTAMB $+(($ KTAMB $-J T A M B) /($ KTIME - JTIME $)) *(T-J T I M E)$

REFVLT=REFTEMP

DO 600 II $=1$, NPTS

REFENV (II) $=$ REFTEMP

600 CONTINUE

700 CONTINUE

RETURN

END 
HNF-3830, Rev. 0

APPENDIX B.

Material Properties.

Table B-1. Dry Air

Table B-2. Medium Carbon Steel

Table B-3. Plutonium Oxide

Table B-4. Concrete 1-2-4 Mix

Table B-5. Stainless Steel 316L 
HNF-3830, Rev. 0

TABLE B-1

Material Properties for Dry Air

Density $(\rho)\left(\mathrm{Kg} / \mathrm{m}^{3}\right)=\rho_{0}\left[1-\beta\left[T-T_{0}\right)\right]$

Where,

$\rho_{0}=$ Reference Density $=1.1774 \mathrm{Kg} / \mathrm{m}^{3}$ at $\mathrm{T}_{0}$

$\mathrm{T}_{0}=$ Reference Temperatures $=300{ }^{\circ} \mathrm{K}$

$\beta=$ Volume Expansion Coefficient. $=1 / \mathrm{T}_{0}{ }^{\circ} \mathrm{K}^{-1}$

$\mathrm{T}=$ Absolute Temperature ( $\left.{ }^{\circ} \mathrm{K}\right)$

\begin{tabular}{|c|c|c|c|}
\hline \multicolumn{4}{|c|}{$\begin{array}{l}\text { Thermal Conductivity }(k) \text {, Specified Heat }(C p) \text {, and Viscosity }(\mu) \\
\text { Versus Temperature }\end{array}$} \\
\hline $\begin{array}{c}\text { Temperature } \\
(\mathrm{K})\end{array}$ & $\begin{array}{c}\text { Thermal } \\
\text { Conductivity } \\
\left(\mathrm{J} / \mathrm{s}-\mathrm{m} \cdot{ }^{\circ} \mathrm{K}\right)\end{array}$ & $\begin{array}{c}\text { Specific } \\
\text { Heat } \\
\left(\mathrm{J} / \mathrm{Kg}-{ }^{\circ} \mathrm{K}\right)\end{array}$ & $\begin{array}{r}\text { Viscosity } \times 10^{5} \\
(\mathrm{Kg} / \mathrm{m}-\mathrm{s}) \\
\end{array}$ \\
\hline 100.0 & 0.009246 & 1026.6 & 0.6924 \\
\hline 150.0 & 0.013735 & 1009.9 & 1.0283 \\
\hline 200.0 & 0.01809 & 1006.1 & 1.3289 \\
\hline 250.0 & 0.02227 & 1005.3 & 1.5990 \\
\hline 300.0 & 0.02624 & 1005.7 & 1.8462 \\
\hline 350.0 & 0.03003 & 1009.0 & 2.075 \\
\hline 400.0 & 0.03365 & 1014.0 & 2.286 \\
\hline 450.0 & 0.03707 & 1020.7 & 2.484 \\
\hline 500.0 & 0.04098 & 1029.5 & 2.671 \\
\hline 550.0 & 0.04360 & 1039.2 & 2.848 \\
\hline 600.0 & 0.04659 & 1055.1 & 3.018 \\
\hline 650.0 & 0.04953 & 1063.5 & 3.177 \\
\hline 700.0 & 0.05230 & 1075.2 & 3.332 \\
\hline 750.0 & 0.05509 & 1085.6 & 3.481 \\
\hline 800.0 & 0.05779 & 1097.8 & 3.625 \\
\hline 850.0 & 0.06028 & 1109.5 & 3.765 \\
\hline 900.0 & 0.06279 & 1121.2 & 3.899 \\
\hline 950.0 & 0.06525 & 1132.1 & 4.023 \\
\hline 1000.0 & 0.06752 & 1141.7 & 4.152 \\
\hline
\end{tabular}

Reference: Holman (1990) 
HNF-3830, Rev. 0

TABLE B-2

Medium Carbon Steel

Density $(\rho)=7852.3 \mathrm{Kg} / \mathrm{m}^{3}$

\begin{tabular}{|c|c|c|}
\hline $\begin{array}{c}\text { Temperature } \\
\left({ }^{\circ} \mathrm{K}\right)\end{array}$ & $\begin{array}{c}\text { Thermal Conductivity } \\
\left(\mathrm{J} / \mathrm{s} \cdot \mathrm{m}-{ }^{\circ} \mathrm{K}\right)\end{array}$ & $\begin{array}{c}\text { Specific Heat } \\
\left(\mathrm{J} / \mathrm{Kg}-{ }^{\circ} \mathrm{K}\right)\end{array}$ \\
\hline 294.27 & 51.733 & 437.53 \\
\hline 310.94 & 51.510 & 450.22 \\
\hline 366.49 & 50.574 & 486.46 \\
\hline 422.05 & 49.368 & 515.21 \\
\hline 477.60 & 47.930 & 538.84 \\
\hline 533.16 & 46.298 & 559.73 \\
\hline 588.72 & 44.508 & 580.25 \\
\hline 644.27 & 42.599 & 602.79 \\
\hline 699.83 & 40.607 & 629.70 \\
\hline 810.94 & 36.525 & 706.20 \\
\hline 922.05 & 32.562 & 828.74 \\
\hline 1033.16 & 29.016 & 1758.5 \\
\hline 1144.27 & 26.187 & 705.89 \\
\hline
\end{tabular}

Reference: Short (1995) 
HNF -3830 , Rev. 0

TABLE B-3

Plutonium Oxide $\left(\mathrm{PuO}_{2}\right)$

Density $(\rho)=2500.0 \mathrm{Kg} / \mathrm{m}^{3}$

\begin{tabular}{|c|c|}
\hline \multicolumn{2}{|c|}{ Specific Heat $(C p)$ versus Temperature $\left({ }^{\circ} \mathrm{K}\right)$} \\
\hline $\begin{array}{c}\text { Temperature } \\
\left({ }^{\circ} \mathrm{K}\right)\end{array}$ & $\begin{array}{c}\text { Specific Heat (Cp) } \\
\left(\mathrm{J} / \mathrm{kg}-\left({ }^{\circ} \mathrm{K}\right)\right.\end{array}$ \\
\hline 300.0 & 258.64 \\
\hline 325.0 & 271.23 \\
\hline 350.0 & 281.34 \\
\hline 375.0 & 289.34 \\
\hline 400.0 & 295.98 \\
\hline 450.0 & 306.13 \\
\hline 500.0 & 313.44 \\
\hline 550.0 & 318.88 \\
\hline 600.0 & 323.07 \\
\hline 650.0 & 324.27 \\
\hline 700.0 & 329.00 \\
\hline 750.0 & 331.16 \\
\hline 800.0 & 332.96 \\
\hline 900.0 & 335.78 \\
\hline 1000.0 & 337.89 \\
\hline 1200.0 & 340.86 \\
\hline 1400.0 & 342.90 \\
\hline
\end{tabular}

For thermal conductivity $(k)$ see Table 2 and Figure 15 Reference: Katz (1990) 
HNF. 3830, Rev. 0

TABLE B-4

Concrete 1-2-4 Mix

\begin{tabular}{||c|c|}
\hline Property & Value \\
\hline $\begin{array}{c}\text { Thermal Conductivity (k) } \\
\left(\mathrm{J} / \mathrm{m}-\mathrm{s}^{\circ} \mathrm{K}\right)\end{array}$ & 0.75363 \\
\hline $\begin{array}{c}\text { Specific Heat (Cp) } \\
\left(\mathrm{J} / \mathrm{kg}-{ }^{\circ} \mathrm{K}\right)\end{array}$ & 627.99 \\
\hline $\begin{array}{c}\text { Density ( } \rho) \\
\left(\mathrm{kg} / \mathrm{m}^{3}\right)\end{array}$ & 2300.14 \\
\hline
\end{tabular}

Reference: Irwin (1993) 
HNF -3830 , Rev. 0

TABLE B-5

Stainless Steel 316L

Density $(\rho)=7962.0 \mathrm{Kg} / \mathrm{m}^{3}$

\begin{tabular}{||c|c|c||}
\hline \hline $\begin{array}{c}\text { Thermal Conductivity (k) and Specific Heat (Cp) Vs Temperature ( } \mathrm{K} \text { ) } \\
\left({ }^{\circ} \mathrm{K}\right)\end{array}$ & $\begin{array}{c}\text { Thermal Conductivity } \\
\left(\mathrm{J} / \mathrm{s}-\mathrm{m}-{ }^{\circ} \mathrm{K}\right)\end{array}$ & $\begin{array}{c}\text { Specific Heat } \\
\left(\mathrm{J} / \mathrm{Kg} \text { - }{ }^{\mathrm{K}} \text { ) }\right.\end{array}$ \\
\hline 294.27 & 13.36 & 465.6 \\
\hline 310.94 & 13.64 & 472.3 \\
\hline 366.49 & 14.58 & 492.4 \\
\hline 422.05 & 15.51 & 509.7 \\
\hline 477.60 & 16.41 & 524.3 \\
\hline 533.16 & 17.31 & 536.6 \\
\hline 588.72 & 18.18 & 547.1 \\
\hline 644.27 & 19.04 & 556.1 \\
\hline 699.83 & 19.88 & 563.9 \\
\hline 810.94 & 21.51 & 577.6 \\
\hline 922.05 & 23.06 & 590.6 \\
\hline 1033.16 & 24.55 & 606.9 \\
\hline 1144.27 & 25.96 & 628.4 \\
\hline
\end{tabular}

Reference: Irwin (1993) 


\section{DISTRIBUTION SHEET}

To

Distribution

Project Title/Work Order

Thermal-Hydraulic Assessment of Concrete Storage Cubicle with

Horizontal 3013 Canister, HNF-3830, Rev. 0

Name

T. E. Arndt

T. A. Flament

F. J. Heard (5)

G. A. Johnson

J. L. Mejia

D. W. Nelson

C. T. O'Neill (2)

J. P. Sloughter

R. W. Szempruch

E. V. Weiss (3)

Central Files

DIMC

DOE/RL Reading ROOm
From

NHC, F. J. Heard

(1)

\begin{tabular}{|c|c|}
\hline MSIN & $\begin{array}{c}\text { Text } \\
\text { With All } \\
\text { Attach. }\end{array}$ \\
\hline B4 - 39 & $x$ \\
\hline Но -34 & $x$ \\
\hline Но -34 & $x$ \\
\hline B4-09 & $x$ \\
\hline $\mathrm{H} 6-03$ & $x$ \\
\hline $\mathrm{H} 6-03$ & $x$ \\
\hline B4-39 & $x$ \\
\hline НО- 34 & $\mathrm{x}$ \\
\hline$T 5-48$ & $x$ \\
\hline $\mathrm{H} 6-\mathrm{O} 3$ & $x$ \\
\hline B 1-07 & $x$ \\
\hline H6- 15 & $x$ \\
\hline $\mathrm{H} 2-53$ & $\mathrm{x}$ \\
\hline
\end{tabular}

\begin{tabular}{l} 
Page 1 of 1 \\
Date March 1999 \\
\hline EDT No. 626231 \\
\hline ECN No.
\end{tabular}

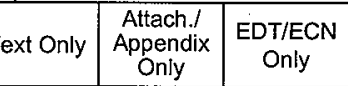

